\title{
Data Compendium for the Columbia River Comprehensive Impact Assessment
}

\author{
P. W. Eslinger \\ L. R. Huesties \\ A. D. Maughan \\ T. B. Miley \\ W. H. Walters
}

April 1994

Prepared for

the U.S. Department of Energy

Under Contract DE-ACO6-76RLO 1830

Pacific Northwest Laboratory

Richland, Washington 99352






\section{DISCLAIMER}

This report was prepared as an account of work sponsored by an agency of the United States Government. Neither the United States Government nor any agency thereof, nor any of their employees, make any warranty, express or implied, or assumes any legal liability or responsibility for the accuracy, completeness, or usefulness of any information, apparatus, product, or process disclosed, or represents that its use would not infringe privately owned rights. Reference herein to any specific commercial product, process, or service by trade name, trademark, manufacturer, or otherwise does not necessarily constitute or imply its endorsement, recommendation, or favoring by the United States Government or any agency thereof. The views and opinions of authors expressed herein do not necessarily state or reflect those of the United States Government or any agency thereof. 


\section{DISCLAIMER}

Portions of this document may be illegible in electronic image products. Images are produced from the best available original document. 


\section{Summary}

The Columbia River Comprehensive Impact Assessment (CRCIA), established in the 1994 amendment of the Hanford Federal Facility Agreement and Consent Order (often referred to as the Tri-Party Agreement, or TPA), supports the TPA milestone number M-13-80 (Submit Compendium of Existing Columbia River Contaminant Data to EPA and Ecology). The CRCIA is conducted by the Pacific Northwest Laboratory (PNL) for the U.S. Department of Energy (DOE). ${ }^{1}$ The purpose of the CRCIA is to evaluate the current human and ecological risk from the Columbia River attributable to past and present activities on the Hanford Site. Human risk will be addressed for radioactive and hazardous materials over a range of river use options. Ecological risk will be evaluated relative to the health of the current river ecosystem.

The initial effort for the CRCIA is the development of a compendium of existing data on Columbia River contamination. This document provides the data compendium. It also includes a discussion of data sources, descriptions of the physical format of the data, and descriptions of the search process used to identify data.

The search for contaminant data identified approximately 4500 documents and 13 major databases that potentially contain information about contaminants in the Columbia River due to activities on the Hanford Site. As described in this document, searches for data were conducted through telephone calls, by electronic means, and through personal visits. Approximately 1750 of the documents identified in the search process are available to the DOE, Washington State Department of Ecology (Ecology), U.S. Environmental Protection Agency (EPA), and the public in the DOE Reading Room in Richland. Approximately 2050 of the documents identified in the search process were not readily available to one or more of DOE, Ecology, EPA, or members of the public. References for these documents are given in electronic format in Appendix A. Over 650 declassified titles of classified documents were recently made available by DOE. Even though the titles were declassified, many of the documents remain classified. The titles of these documents are provided in Appendix B.

Approximately 60 key documents are listed in Section 4.2. These key documents contain data or describe analyses important to evaluating the health of the Columbia River. The complete document reference lists and database identifications are provided in a series of appendixes. Because of their extensive length, several of the appendixes are provided in ASCII files on an accompanying diskette.

This data compendium identifies data locations through document references and database identification. As required by TPA Change Order number M-13-93-06, the data identified in this compendium will be made available to the Tri-Party agencies and to interested stakeholders.

This report identifies a large number of documents that may contain data about Columbia River contaminants originating at Hanford. Only a small number of the documents have been reviewed at this time to determine their relevence to conducting a human or ecological impact assessment.

\footnotetext{
'Pacific Northwest Laboratory is operated for the U.S. Department of Energy by Battelle Memorial Institute.
} 


\section{Abbreviations and Acronyms List}

\begin{tabular}{|c|c|}
\hline ATSDR & Agency for Toxic Substances and Disease Registry \\
\hline BNW & Battelle, Pacific Northwest Laboratories \\
\hline BPA & Bonneville Power Administration \\
\hline $\mathrm{CDC}$ & Centers for Disease Control and Prevention \\
\hline CERCLA & Comprehensive Environmental Response, Compensation, and Liability Act of 1980 \\
\hline CRCIA & Columbia River Comprehensive Impact Assessment \\
\hline CRRD & Columbia River Reference Database \\
\hline DEQ & Department of Environmental Quality \\
\hline DOE & U.S. Department of Energy \\
\hline DOE-RL & U.S. Department of Energy, Richland Operations Office \\
\hline Ecology & Washington State Department of Ecology \\
\hline EMDD & Environmental Monitoring Document Database \\
\hline EPA & U.S. Environmental Protection Agency \\
\hline ERS & Environmental Release System \\
\hline $\mathrm{HAB}$ & Hanford Advisory Board \\
\hline HEDR & Hanford Environmental Dose Reconstruction \\
\hline HEIS & Hanford Environmental Information System \\
\hline HEW & U.S. Department of Health, Education, and Welfare \\
\hline HGIS & Hanford Geographical Information System \\
\hline HIRTS & Hanford Information Resource Tracking System \\
\hline HMS & Hanford Meteorological System \\
\hline HWMA & Washington State Hazardous Waste Management Act of 1976 \\
\hline LEMIS & Liquid Effluent Monitoring Information System \\
\hline NED & Northwest Environmental Database \\
\hline NPDES & National Pollutant Discharge Elimination System \\
\hline NPL & National Priorities List \\
\hline NTIS & National Technical Information Service \\
\hline PDMS & Project and Data Management System \\
\hline PNL & Pacific Northwest Laboratory \\
\hline PNWD & Pacific Northwest Division \\
\hline RCRA & Resource Conservation and Recovery Act of 1976 \\
\hline RL & Richland Operations Office \\
\hline SACS & Surveillance Analysis Computer System \\
\hline SESP & Surface Environmental Surveillance Project \\
\hline SWTTS & Solid Waste Information and Tracking System \\
\hline TCD & Tank Characterization Database \\
\hline TPA & Tri-Party Agreement (Hanford Federal Facility Agreement and Consent Order) \\
\hline TSP & Technical Steering Panel \\
\hline USGS & U.S. Geological Survey \\
\hline USPHS & U.S. Public Health Service \\
\hline WDS & Waste Information Data System \\
\hline WPPSS & Washington Public Power Supply System \\
\hline
\end{tabular}




\section{Contents}

Summary $\ldots \ldots \ldots \ldots \ldots \ldots \ldots \ldots \ldots \ldots \ldots \ldots \ldots \ldots \ldots \ldots \ldots \ldots \ldots \ldots$ iii

Abbreviations and Acronyms List $\ldots \ldots \ldots \ldots \ldots \ldots \ldots \ldots \ldots \ldots \ldots \ldots \ldots$

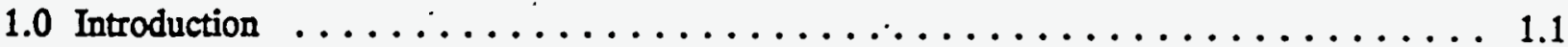

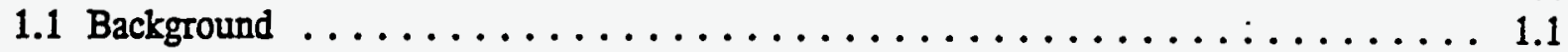

1.2 Purpose . . . . . . . . . . . . . . . . . . . . . . . . 1.2

1.3 Short History of Site Operations $\ldots \ldots \ldots \ldots \ldots \ldots \ldots \ldots \ldots \ldots \ldots \ldots \ldots$

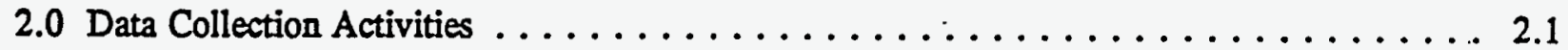

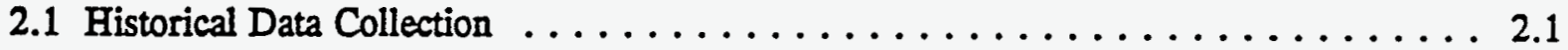

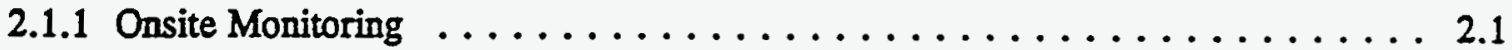

2.1.1.1 Monitoring from 1945 through $1957 \ldots \ldots \ldots \ldots$. . . . . . . . . . 2.1

2.1.1.2 Monitoring from 1958 through $1971 \ldots \ldots \ldots \ldots \ldots$. . . . . . . . . . 2.2

2.1.1.3 Monitoring from 1972 to $1994 \ldots \ldots \ldots \ldots \ldots \ldots \ldots . \ldots \ldots$

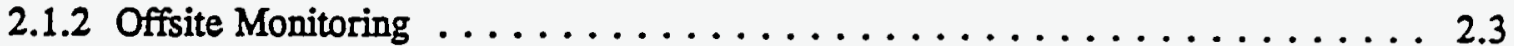

2.2 Data Collection Currently in Progress . . . . . . . . . . . . . . . . . . 2.4

2.2.1 Surface Environmental Surveillance Project . . . . . . . . . . . . . . 2.5

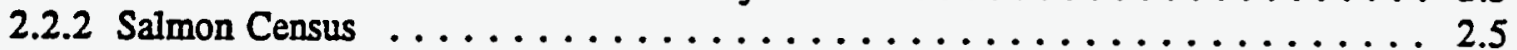

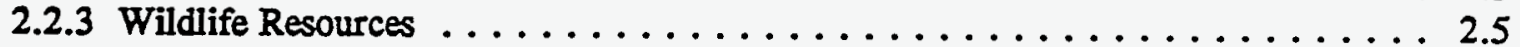

2.2 .4100 Area Monitoring . . . . . . . . . . . . . . . . . . . . 2.5

2.2.5 Washington State Department of Health . . . . . . . . . . . . . . 2.5

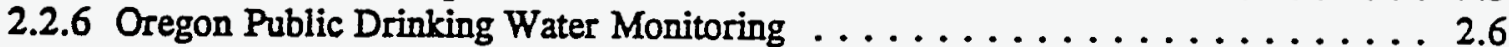

2.2 .7 Washington Public Power Supply System . . . . . . . . . . . . . . . 2.6

2.2 .8 U.S. Geological Survey . . . . . . . . . . . . . . . . . . . . . 2.6

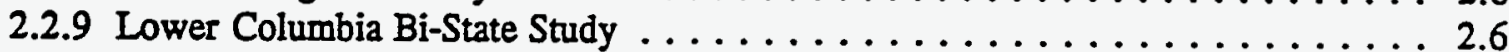

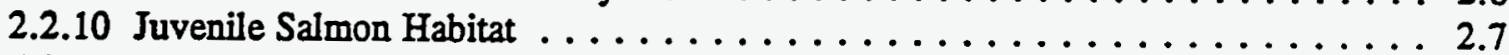

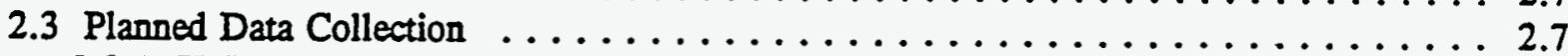

2.3.1 U.S. Geological Survey . . . . . . . . . . . . . . . . . . 2.7

2.3.2 National Marine Fisheries Agency $\ldots \ldots \ldots \ldots \ldots \ldots \ldots \ldots \ldots \ldots \ldots . \ldots \ldots$

2.3.3 Agency for Toxic Substances and Disease Registry . . . . . . . . . . 2.8

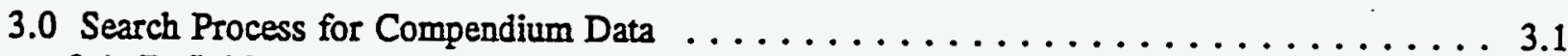

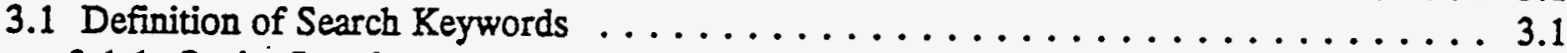

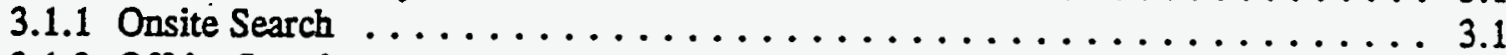

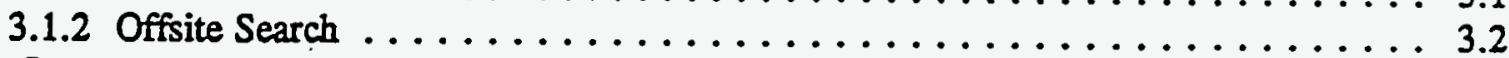

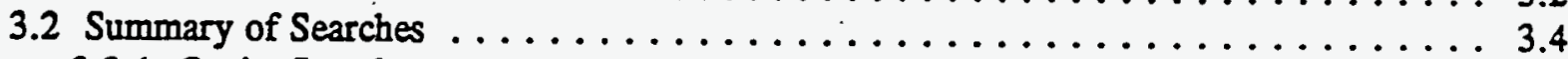

3.2 .1 Onsite Searches . . . . . . . . . . . . . . . . . . . . 3.4

3.2.1.1 DOE Reading Room, Richland, Washington . . . . . . . . . . 3.4

3.2.1.2 Hanford Technical Library . . . . . . . . . . . . . . . . 3.4

3.2.1.3 Hanford Technical Reports . . . . . . . . . . . . . . . . . 3.5

3.2.1.4 Environmental Restoration Program Information Center . . . . . . . . . . 3.5

3.2.1.5 Administrative Record Center . . . . . . . . . . . . . . 3.5

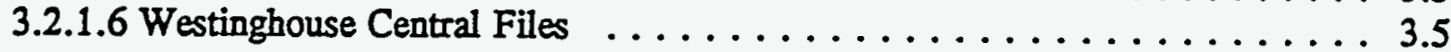


3.2.1.7 NPDES Permits $\ldots \ldots \ldots \ldots \ldots \ldots \ldots \ldots \ldots \ldots \ldots \ldots \ldots .6 \ldots \ldots$

3.2.1.8 DOE Records Holding Area . . . . . . . . . . . . . 3.6

3.2.1.9 Washington Public Power Supply System $\ldots \ldots \ldots \ldots \ldots \ldots \ldots \ldots .6$

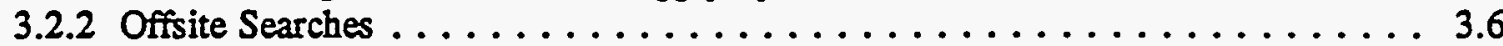

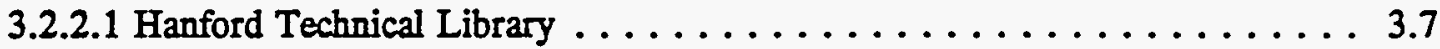

3.2.2.2 NPDES Permits Not at Hanford . . . . . . . . . . . . 3.8

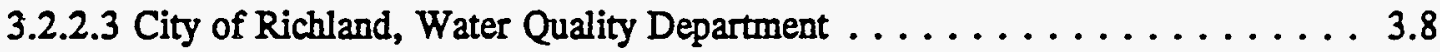

3.2.2.4 American Waterworks Association $\ldots \ldots \ldots \ldots \ldots \ldots \ldots \ldots \ldots .8$

3.2.2.5 State of Washington, Division of Social and Health Services . . . . . . 3.8

3.2.2.6 University of Washington . . . . . . . . . . . . . . . . . 3.8

3.2.2.7 State of Oregon, Department of Human Resources . . . . . . . . . 3.9

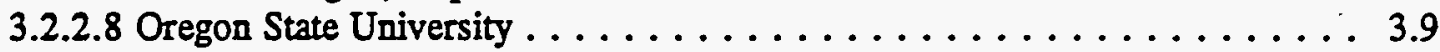

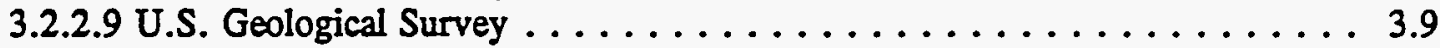

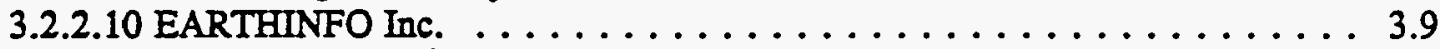

3.2.2.11 Pacific Northwest River Basin Commission . . . . . . . . . . 3.9

3.2.2.12 U.S. Department of Health, Education, and Welfare . . . . . . . 3.9

4.0 Results . . . . . . . . . . . . . . . . . . . . . . 4.1

4.1 Results of the Compendium Data Search $\ldots \ldots \ldots \ldots \ldots \ldots \ldots \ldots \ldots .1$

4.1 .1 Database Identification . . . . . . . . . . . . . . . . . . 4.1

4.1 .2 Unpublished Information $\ldots \ldots \ldots \ldots \ldots \ldots \ldots \ldots \ldots \ldots .1$

4.1.3 Published Information That is Publicly Available $\ldots \ldots \ldots \ldots \ldots \ldots .1$

4.1.4 Documents Not Publicly Available $\ldots \ldots \ldots \ldots \ldots \ldots \ldots \ldots \ldots \ldots .1$

4.1.5 Formerly Classified Titles $\ldots \ldots \ldots \ldots \ldots \ldots \ldots \ldots \ldots \ldots \ldots .2$

4.2 Key Documents . . . . . . . . . . . . . . . . . . . 4.2

4.2.1 General and Historical Documents $\ldots \ldots \ldots \ldots \ldots \ldots \ldots \ldots \ldots .4$

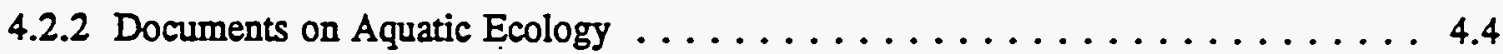

4.2.3 Documents on General River Monitoring . . . . . . . . . . . . 4.5

4.2 .4 Documents on Ecological Assessments . . . . . . . . . . . . 4.6

4.2.5 Site Environmental Monitoring and Field Investigations $\ldots \ldots \ldots \ldots \ldots .6 .6$

4.2.6 Documents from Non-Hanford Sources $\ldots \ldots \ldots \ldots \ldots \ldots \ldots \ldots .8$

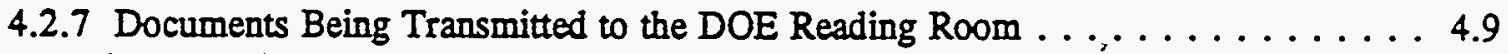

4.2.7.1 Books Ordered for the DOE Reading Room . . . . . . . . . . 4.9

4.2.7.2 Reports Transmitted to the DOE Reading Room . . . . . . . . . 4.9

5.0 Future Activities in Data Management $\ldots \ldots \ldots \ldots \ldots \ldots \ldots \ldots \ldots \ldots \ldots \ldots \ldots \ldots$

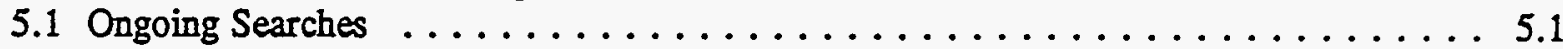

5.2 Methods for Transferring Data to the Public . . . . . . . . . . . . . 5.1

5.2.1 Transfer Methods for Paper Documents Based on Current Availability . . . . . . 5.1

5.2.1.1 Documents Already Approved for Release $\ldots \ldots \ldots \ldots \ldots \ldots \ldots . .2$

5.2.1.2 Documents Approved Only for Company or Client Use . . . . . . . 5.2

5.2.1.3 Unpublished Documents and Records $\ldots \ldots \ldots \ldots \ldots \ldots \ldots .2$

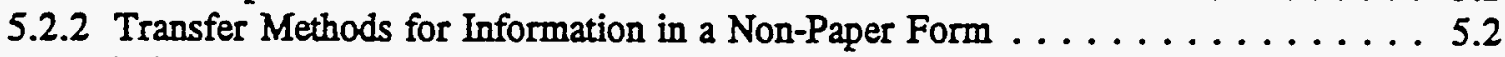

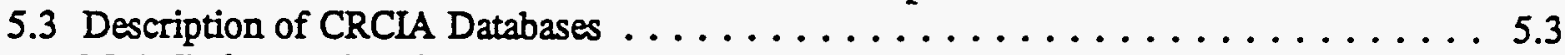

5.3 .1 Reference Database . . . . . . . . . . . . . . . . . 5.3

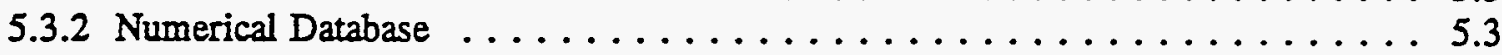


6.0 References $\ldots \ldots \ldots \ldots \ldots \ldots \ldots \ldots \ldots \ldots \ldots \ldots \ldots \ldots \ldots .1$

Appendix A - Published Information Not Currently Available to the Public $\ldots \ldots \ldots \ldots$ A.1

Appendix B - Formerly Classified Titles $\ldots \ldots \ldots \ldots \ldots \ldots \ldots \ldots \ldots \ldots \ldots$ B.1

Appendix C - Description of Databases $\ldots \ldots \ldots \ldots \ldots \ldots \ldots \ldots \ldots \ldots \ldots \ldots \ldots \ldots \ldots$

Appendix D - Documents Already in the Public Domain ............... D.1

\section{Figures}

1.1 Map of the Hanford Site $\ldots \ldots \ldots \ldots \ldots \ldots \ldots \ldots \ldots \ldots \ldots \ldots \ldots \ldots \ldots .3 .3$

2.1 Columbia River Sampling Locations - Washington and Oregon $\ldots \ldots \ldots \ldots \ldots .4 .4$

\section{Table}

2.1 Current and Future Columbia River Sampling Activities $\ldots \ldots \ldots \ldots \ldots \ldots \ldots$ 


\subsection{Introduction}

\subsection{Background}

As a result of past practices, four areas of the Hanford Site (the 100, 200, 300, and 1100 -Areas) have been included on the U.S. Environmental Protection Agency's (EPA) National Priorities List (NPL) under the Comprehensive Environmental Response, Compensation, and Liability Act of 1980 (CERCLA). In addition to the four NPL sites, more than 60 Resource Conservation and Recovery Act of 1976 (RCRA) treatment, storage, or disposal facilities will be closed or permitted to operate in accordance with RCRA regulations. To accomplish the timely cleanup of the four sites affected by past practices, the Hanford Federal Facility Agreement and Consent Order (often referred to as the Tri-Party Agreement, or TPA), (Ecology et al. 1989) was signed by the Washington State Department of Ecology (Ecology), EPA, and the U.S. Department of Energy (DOE).

- Milestones have been adopted for the TPA that identify actions needed to ensure acceptable progress toward Hanford Site compliance with CERCLA, RCRA, and the Washington State Hazardous Weste Management Act of 1976 (HWMA). In January 1994, DOE, EPA, and Ecology signed an agreement and action plan that resulted in a revised TPA (Ecology et al. 1994). One of the revisions (Change Order number M-13-93-06) reflects adjustments made to milestones designed to address cleanup strategies and achieve timely remedial decisions and actions concerning the Columbia River.

The Columbia River Comprehensive Impact Assessment (CRCIA), established in TPA Milestone M-13-80, will evaluate the current human and ecological risks from the Columbia River attributable to past and present activities on the Hanford Site. The CRCIA is conducted by the Pacific Northwest Laboratory (PNL) for the DOE. ${ }^{2}$ Human risk from exposure to radioactive and hazardous materials will be addressed for a range of river use options. Ecological risk will be evaluated relative to the health of the current river ecosystem.

The initial effort for the CRCIA is the development of a compendium of existing data on Columbia River contamination. The data compendium activity will be followed by a workshop that will discuss the data on contaminants in the Columbia River from Hanford Site operations and the potential human health and environmental impacts from these contaminants. The affected American Indian Tribes, the States of Oregon and Washington, the Hanford Advisory Board (HAB), and the public will be invited to attend the workshop.

Subsequently, the data that currently exist will be collected and made available to Ecology, and EPA. A copy of the data will be transmitted to the DOE Reading Room in Richland, or in the case of databases (see Appendix C), an access mechanism will be defined. A determination will be made as to whether human health and environmental risk assessments can be performed with existing data. The TPA milestone requires reporting of existing data on Hanford-derived contamination to the Columbia River both in the Hanford Reach and downstream to the ocean. This requirement sets the geographic constraints on the data search. Institute.

${ }^{2}$ Pacific Northwest Laboratory is operated for the U.S. Department of Energy by Battelle Memorial 


\subsection{Purpose}

This document provides a data compendium of documents and databases describing contaminants released to the Columbia River due to activities at the Hanford site. This data compendium was developed in support of TPA Milestone M-13-80. It includes a discussion of data sources, descriptions of the physical format of the data, and discussions of the search processes used to identify data.

A number of key documents are listed in Section 4.2. These key documents are a subset of the approximately 4500 documents have been identified as potentially containing data about contamination in the Columbia River. References for all of these documents are given in a series of appendixes grouped by availability of the document to the public. Information about electronic databases is also given in an appendix.

As discussed in Change Order number M-13-93-06, the data identified in this report will be made available to the TPA agencies and to interested stakeholders. This compendium also serves as the forum for introducing the CRCIA project plans to manage the document references and data used in the study and to make the data available to the public.

Milestone M-13-80 establishes the CRCIA to evaluate the current human and ecological risks from exposure to contaminants in the Columbia River that are attributable to past and present activities on the Hanford Site. Historical data for the site are included in this data compendium to provide the information needed to establish a list of contaminants that may have had, or still have, impacts on human health or the ecosystem of the river.

\subsection{Short History of Site Operations}

The DOE operated nine production reactors $(B, C, K W, K E, D, D R, H, F$, and $N$ ) between 1944 and 1971 along the Hanford Reach of the Columbia River (see Figure 1). The Hanford Reach of the Columbia River extends 51 miles downstream from Priest Rapids Dam to the head of the McNary Pool just north of the city of Richland. Eight of these reactors have been deactivated and retired. Except for the $\mathrm{N}$ reactor, all reactors used once-through cooling systems that released radionuclides, process chemicals, including chemicals that inhibited corrosion, and heated water into the river. Radionuclides (such as zinc-65) resulting from operation and cooling of the reactors have been measured in both water and biota along the Columbia River from the Hanford Reach to the ocean.

The $\mathrm{N}$ reactor, which used a closed-loop primary cooling system, operated between 1963 and 1987. It has been defueled and is in the process of deactivation. While in operation, this reactor discharged a significant amount of heat to the river, but a lesser amount of radioactivity was associated with its effluent than with the other eight reactors. 


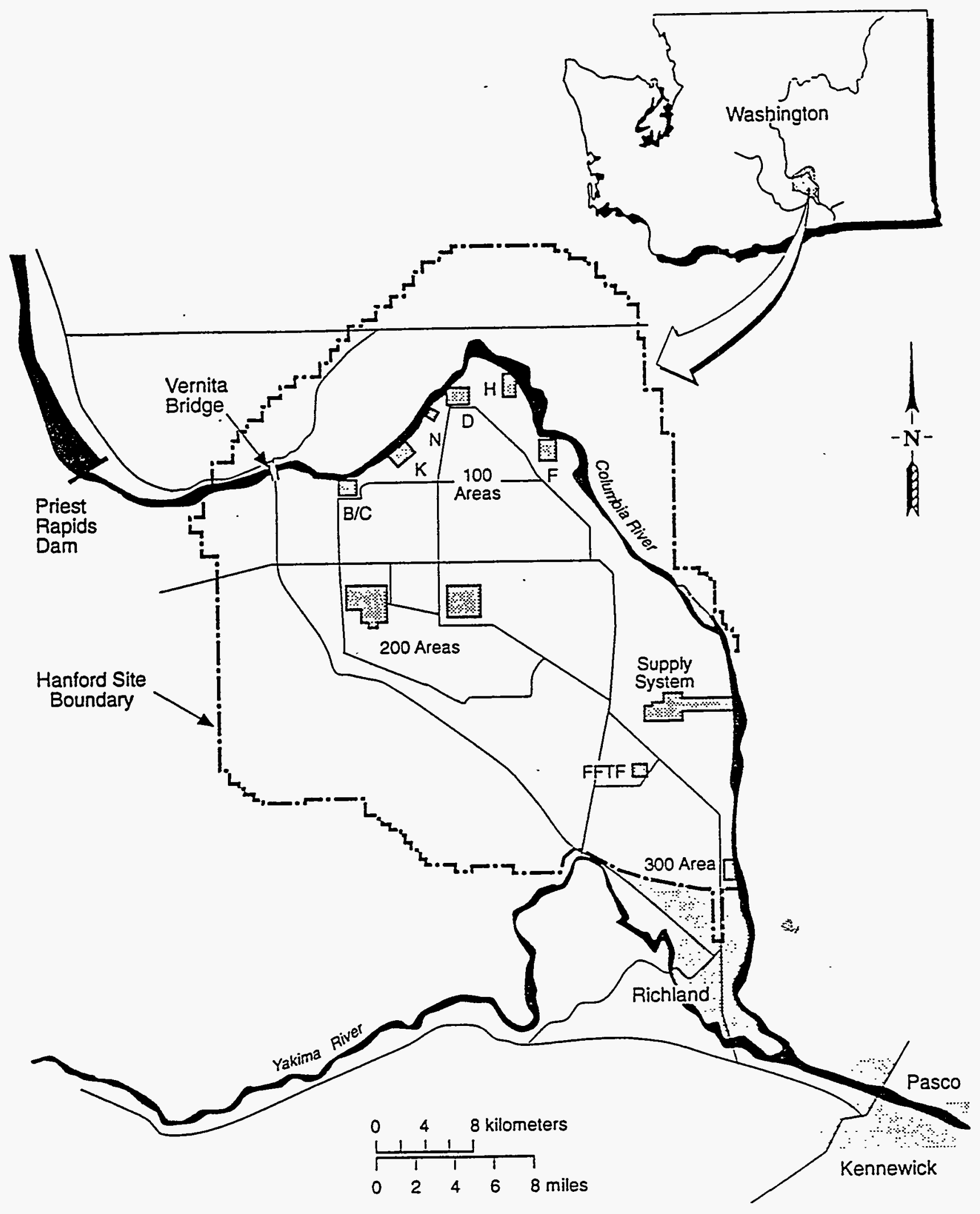

Figure 1.1. Map of the Hanford Site

\$9404084.1 
Direct discharge of radionuclides to the river by the DOE reactors was virtually eliminated when the last of the reactors (KE) using a once-through cooling system was shut down in 1971. Similarly, the discharge of chemical contaminants was significantly reduced. At present, relatively small amounts of contaminated ground water continue to discharge through seeps and springs to the river (Dirkes 1994, DOE-RL 1993).

Various contaminants are present in the Columbia River environs as a result of past and present operations at Hanford, as well as from other sources. Past operations of Hanford's processing plants (for example, $B$ and $T$ plants, Plutonium Uranium Extraction Plant, and Plutonium Finishing Plant) resulted in contaminated effluents, some of which are making or have made their way to the river through the ground water. Relatively low concentrations of tritium, strontium-90, iodine-129, and natural uranium have been consistently measured in the Columbia River water. Constituents from these effluents, and others such as nitrates and chromium, have been monitored in springs, seeps, sediments, vegetation, and biota associated with the Hanford Reach. 


\subsection{Data Collection Activities}

Many data relevant to the Columbia River environment have been collected since the start-up of Hanford operations. For a variety of purposes environmental measurements and observations have been performed by numerous organizations, outside the Hanford domain as well as within. This section describes the known monitoring activities that have been conducted, are currently being conducted, or will be conducted in the future:

\subsection{Historical Data Collection}

Site contractors began initial monitoring at the Hanford Site in 1945. Also, beginning about 1950 , offsite federal and state agencies began monitoring programs and studies at river locations downstream of Hanford, including the coastal areas.

\subsubsection{Onsite Monitoring}

The historical monitoring on the Hanford Site can be divided into three periods: 1945 through 1957, 1958 through 1971, and 1972 to the present. These times correspond reasonably well with periods of 1) significant developments in analytical techniques, 2) programmatic modifications that resulted in changes in the rationale for and purposes of the programs, and 3) sequential reactor shutdowns that resulted in significant reductions in contaminant loading to the river (Walters et al. 1992).

\subsubsection{Monitoring from 1945 through 1957}

Initial monitoring of Columbia River water began early in 1945, following the startup of the first three reactors $(100-\mathrm{B}, 100-\mathrm{D}$, and 100-F). The primary objective was the detection, but not quantification, of reactor-created radionuclides. However, shortly after the startup of reactors, the need to measure radionuclide quantities in the river was recognized, and routine sampling began.

The first sampling locations selected were at the 100-B, 100-D, and 100-F areas, the Hanford Townsite, the 300 Area, and Richland. A station at Pasco was added in 1945. From the late 1940s through 1957, the Columbia River monitoring program was expanded to downstream locations, providing a significant amount of data on total beta activities. Monitoring for specific radionuclides was begun about the end of this period. The sampling locations were extended downstream to the Portland, Oregon vicinity. This included key locations at McNary Reservoir and Dam, Celilo, The Dalles and Hood River, Oregon, and Bonneville Dam. Sampling of the Yakima River near its confluence with the Columbia River and at the mouth of the Snake River were also added.

Monitoring of Columbia River sediment was initiated in 1948. Through 1957, sediment samples were routinely collected at various locations that included shoreline and riverbed samples. The results were reported as measurements of total beta activity. Most of the sampling locations were in the Hanford Reach down to McNary Dam. The Yakima and Snake river confluences were included. The farthest downstream sampling location was at Paterson, Washington about 20 river miles below McNary Dam. 
Before and during the early days of operations at Hanford, concern was voiced about the impact of discharging radioactive material into the Columbia River and the uptake of such material by fish. As a result numerous special studies, both laboratory and in-stream, were established during the early operating period. Routine sampling of Columbia River whitefish at Hanford began in 1950. Whitefish were chosen because they were available year-round and had some of the highest concentration factors of radionuclides (Walters et al. 1992). Numerous other species were gradually added to the monitoring program (for example, trout, salmon, bass, perch). The sampling was confined to areas upstream and downstream of the operating facilities and at areas popular with local fishermen.

Routine monitoring for radioactive substances of various shellfish, primarily oysters, was conducted in the marine environment near the mouth of the Columbia River. Willapa Bay, the major oyster-growing area near the river mouth, was chosen as the primary sample collection site. No known monitoring was conducted for other hazardous substances in this time period.

\subsubsection{Monitoring from 1958 through 1971}

During the sampling period of 1945 through 1958, analytical capabilities were limited and total alpha and total gross beta measurements were the only data available. By 1958, gamma energy spectroscopy was available and analysis for specific radionuclides was possible. Also, by 1957, the purpose of the river monitoring program had changed from detection of Hanford-derived contaminants to quantification and dose evaluation. This change resulted in a modified program that optimized the amount and type of river data collected. The program focused on the potential radiation doses received by the public living near and using the Columbia River. Several of the sampling stations were discontinued, but the length of river studied still extended to Portland.

Routine monitoring from 1958 through 1971 provided an indication of the isotopic burden of various radionuclides in the river resulting from Hanford operations. The monitoring program established in the early 1960 s is the predecessor of today's Surface Environmental Surveillance Project (SESP) surface water monitoring task. Locations upstream of Hanford were established so the contribution of Hanford releases could be distinguished from weapons testing fallout. A sampling station was also established at the Richland water supply intake. Another modification was the initiation of composite sampling to replace the grab sampling method. This new method provided more accurate weekly estimates of radionuclide concentrations and provided some assurance that short-term elevated releases (such as fuel element failures) were observed. Continuous sampling systems (filter/resin) were put into service in later years to increase the sample size for detection of radionuclides at low concentrations. Radionuclides of primary interest in river water were tritium, sodium-24, phosphorus-32, chromium-51, zinc-65, arsenic-76, strontium-90, iodine-131, and cesium137.

For the 1958 through 1971 period, sediment was sampled only in 1959. Routine sampling of shoreline and river-bed sediments was discontinued in 1960 because the data were not useful in the direct calculation of doses to humans.

The sampling of fish from the Columbia River and shellfish from coastal areas near the river mouth remained in the program for the period 1958 through 1971. Whitefish remained the primary species sampled with the sampling locations identified as areas. The areas were upstream of and immediately downstream from the operating reactors, and downstream of Hanford at areas known to 
be frequented by the local fisherman. Oysters harvested in Willapa Bay were obtained from a commercial market in Portland, Oregon. Radionuclides of interest in fish and shellfish were zinc-65 and phosphorus-32. No known monitoring was conducted for other hazardous substances in this time period.

\subsubsection{Monitoring from 1972 to 1994}

At the present time, samples of river water continue to be collected routinely at several locations. All sampling stations are within the Hanford Reach, except the station at the Bonneville Dam. The primary interest of the monitoring program since its restructuring in the 1960 s has been the calculation of dose to humans using or consuming river water. Water samples are analyzed for gross alpha, gross beta, gamma emmiters, tritium, strontium-90, technetium-99, iodine-129, isotopic plutonium, and isotopic uranium.

Routine sediment sampling was reestablished in 1988 with the initial sampling behind Priest Rapids Dam and McNary Dam. The program was expanded to include locations at White Bluffs slough, the 100-F Area slough, the Hanford slough and Richland. In contrast to the water sampling, sediment samples are analyzed for gamma emmiters, tritium, strontium- 90 , isotopic plutonium, and isotopic uranium.

The sampling of various fish continues to the present. Whitefish is still the primary species sought. By 1972, all of the reactors with a single-pass cooling system had been shut down, leading to a decline of radioactivity in the Columbia River. The number and diversity of fish samples has also declined steadily over the years since 1972 (Cushing et al. 1981). The radionuclides of concern include strontium-90, tritium, and several gamma emitters. The routine sampling of oysters from Willapa Bay was discontinued in 1978 because the remaining zinc-65 had decayed.

Recent hazardous wastes regulatory requirements and a changing mission at Hanford have increased concerns about hazardous chemical contaminants released to the Columbia River through bankline springs. During the late 1980s, initial investigations indicated that additional information on the type, concentrations, transport, fate, and environmental significance of chemical contaminants in the river was needed. Therefore, the chemical monitoring element of the Columbia River Monitoring Program was expanded to include metals, anions, and volatile organic compounds. Water sampling for these constituents began during the last four months of 1991. Sampling was performed quarterly during the following years at Vernita Bridge (upstream of Hanford) and at the Richland pumphouse (Dirkes et al. 1993).

\subsubsection{Offsite Monitoring}

The first comprehensive offsite radiological monitoring of the Columbia River was conducted by the U.S. Public Health Service (USPHS) beginning in 1951 and continuing into 1953. The USPHS monitored water quality and biota, reporting the results as gross beta. The sampling was limited to the river section between Will's Ranch (near 100-B reactor) and Paterson, Washington, downstream of McNary Dam. Brief, exploratory surveys were conducted at Bonneville Dam and Portland, Oregon. These surveys provided the first independent comparison of Hanford data (Robeck et al. 1954). Offsite sampling locations are shown on Figure 2.1. 


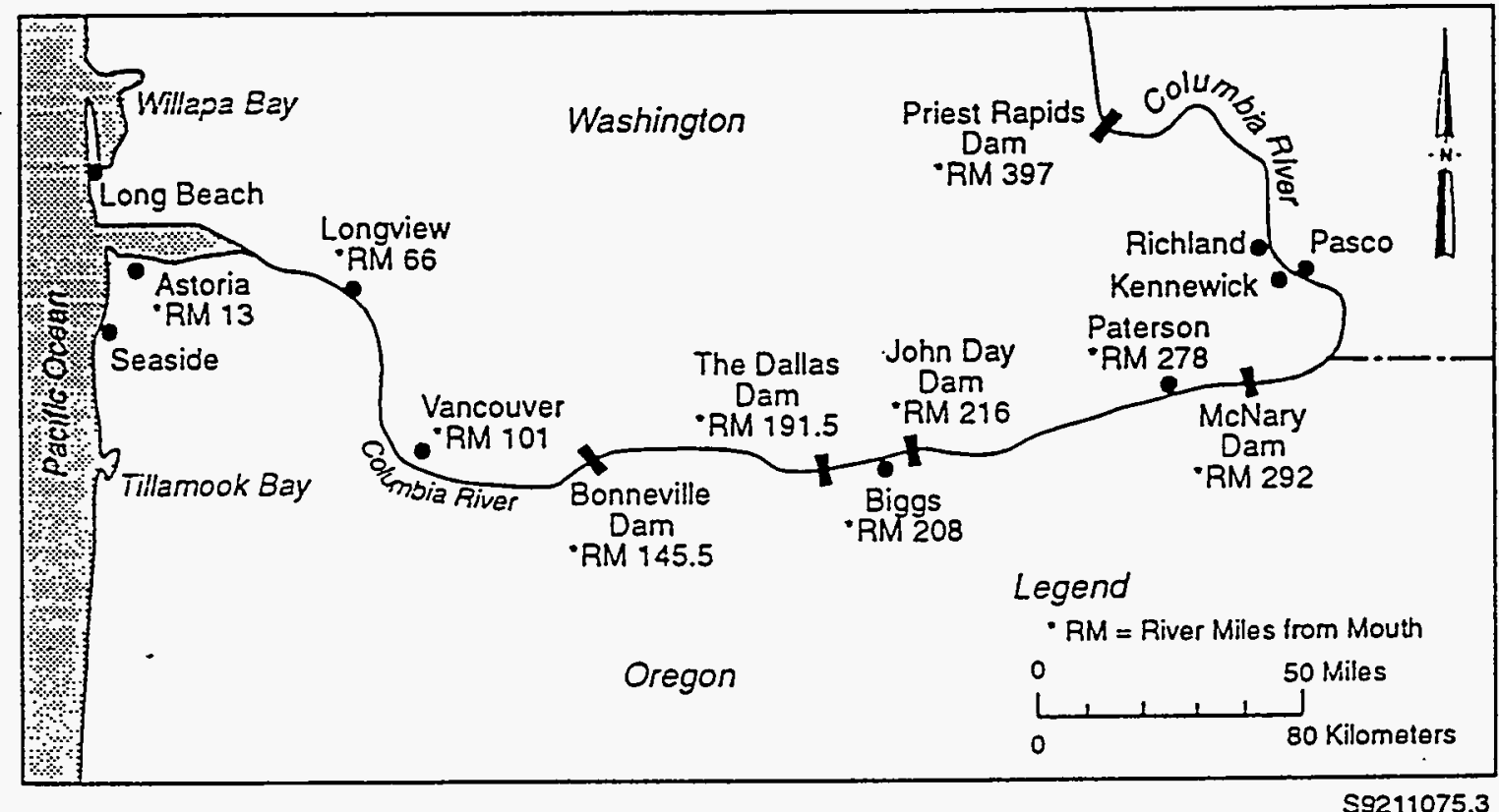

Figure 2.1. Columbia River Sampling Locations - Washington and Oregon

Beginning in the early 1960s, offsite agencies began a series of studies and monitoring programs that involved the states of Washington and Oregon, the University of Washington, Oregon State University, and the U.S. Geological Survey. Most of the data are scattered in numerous reports and specific to a particular limited study. The most useful data were those radionuclide concentrations measured in fish and shellfish. The one comprehensive database was collected by the Oregon State Department of Health. From 1961 through 1977, Columbia River water, as well as estuarine and coastal fish and shellfish, was sampled from The Dalles downstream to the mouth of the river. Since 1977, the program has been conducted each year but at a much reduced level of effort. Sampling was primarily conducted on a quarterly basis for each year. Some sediment samples were included. The radionuclides of interest were zinc- 65 and chromium-51, although other radionuclides were considered. The U.S. Geological Survey collaborated with Hanford contractors during the early to mid-1960s, but did not collect data on a continuing basis. The overall objective of the studies was to determine the transport and deposition of Hanford radionuclides along the Columbia River.

\subsection{Data Collection Currently in Progress}

Recently, a survey was conducted of various agencies to determine what data collection activities are either currently being conducted or are planned for the future. Most of the current activities are ongoing and will continue. The following is a summary of the data collection activities that were discovered in this investigation. 


\subsubsection{Surface Environmental Surveillance Project}

This project at Pacific Northwest Laboratory (PNL) includes sampling of river water, sediments, river banks, springs, fish, clams, crayfish, and riparian vegetation. Shoreline radiation dosimeters continuously collect monitoring data for radionuclides only. The data are reported annually with spreadsheets available electronically (see Appendix C). The near-river ground water contaminants are monitored to characterize discharge (volume) to the river and ground water/river interaction.

\subsubsection{Salmon Census}

A census is conducted periodically by PNL using aerial surveys to monitor numbers of spawning fall chinook salmon. PNL also conducts radio telemetry studies to characterize their distribution and pre-spawning behavior. A database is maintained that contains information on annual spawning surveys made since 1948.

\subsubsection{Wildlife Resources}

This project at PNL collects data on eagle abundance and salmon spawning each fall, goose nesting each spring, and riparian plant species each spring. The areas of interest are the islands and riparian areas of the Hanford Reach.

\subsubsection{Area Monitoring}

Monitoring is conducted by DOE contractors in the 100 Area to study the effluent from the nuclear facilities, particularly the seeps and discharges from buildings, drain fields, and trenches. Springs and near-river soils, vegetation, and the ground water are monitored during the late winter and early spring (high flow periods), through the summer, and into the fall. Some small animal collection is done in accordance with their availability; for example, mice may be collected when they are in the vicinity of the trenches. Near-river studies of soil and vegetation (including mulberry trees) have been done near the 100 Area facilities. Data from these activities are reported annually and the associated databases are available electronically.

Several remedial investigation/feasibility study reports have been released for the CERCLA 300-FF-5 source and ground water operable units. The reports describe river and spring sampling, ground water well data, biota (both aquatic and riparian zone) sampling of vegetation, and small animal sampling.

\subsubsection{Washington State Department of Health}

The Washington State Department of Health issues permits and inspects municipal water systems. They monitor compliance with drinking water standards for both radioactive and nonradioactive materials and also conduct an Environmental Radiation Monitoring Program (Washington State Department of Health 1993). The Environmental Radiation Monitoring Program includes monitoring surface water, sediments, and fish. Under the direction of this program, the cities of Richland, Pasco, and Kennewick, and other cities downstream draw part of their water supplies from the Columbia River. 


\subsubsection{Oregon Public Drinking Water Monitoring}

Oregon public drinking water intake locations (such as James River, St. Helens, and Rainier) are sampled for bacteria, radionuclides, asbestos, and chemicals (common ions, pesticides, lead and copper, and volatile organic compounds). The sampling frequency may vary depending on population of the city. For example, the asbestos sampling frequency can vary from three to nine years, depending on city size. It is unclear if the samples are collected from the river at the point of intake or from the distribution system, following some treatment.

\subsubsection{Washington Public Power Supply System}

The Washington Public Power Supply System (WPPSS) annually reports the results of radiological impact on the environment near the Number 2 nuclear reactor. Air, water, milk, soil sediments, fish, and garden produce have been collected on an annual basis. The power plant is approximately three miles from the Columbia River, so most environmental samples focus on the near-plant impacts and not on the river. However, water and sediments are sampled about two miles upstream and downstream from river intake and discharge points. Sampling of migrating fish is carried out in May and October.

\subsubsection{U.S. Geological Survey}

The U.S. Geological Survey (USGS) does hourly monitoring at the Vernita Bridge for surface water flow, maximum, minimum, and mean temperatures, as well as collection of five samples per year to characterize water quality: specific conductance, $\mathrm{pH}$, dissolved oxygen, turbidity, hardness, and bacteria. The station also records discharge flows from the Priest Rapids Dam. At the Richland Bridge Pumping Plant, 4.8 miles upstream from the confluence of the Columbia River with the Yakima, hourly temperature measurements have been recorded, and some water quality parameters are measured. In 1994, hourly water temperature recordings analyses for metals were discontinued at both stations. Below the Hanford Reach, the following measurements are made by the USGS:

Stevenson, Washington - temperature data

Washougal, Washington - Stage recording.

The Dalles, Oregon - discharge data

Bonneville Dam - Stage recording (elevation)

Warrendale, Oregon - Water quality

The USGS is also currently studying Columbia River dioxins, furans, and heavy metals that originate at the Trail, British Columbia, lead smelting complex.

\subsubsection{Lower Columbia Bi-State Study}

This study was designed to collect baseline data needed for an evaluation of siting potential pulp mills on the lower Columbia. The study, begun in 1991, is ongoing and addresses the section of the river from Bonneville Dam downstream. Samples were collected to determine concentrations of dioxin, water quality parameters, nutrients, toxic metals, and radionuclides. The Washington State Department of Ecology and the Oregon Department of Environmental Quality (DEQ) are cooperating on the performance of the work. This multiphase ongoing reconnaissance study: 
1) evaluates the river condition (water quality) based on existing information and data. In order to assess the current quality of the Columbia, two one-time studies were made of the river below the Bonneville Dam. The USGS, Ecology, and Oregon DEQ have cooperated on this activity. A report has been written.

2) discusses the emission sources that discharge to the lower Columbia. A report has been written.

3) provides for monthly monitoring of the river at nine locations (five are directly on the river). Among the parameters are water quality, suspended solids, polyaromatic hydrocarbons, common ions, trace elements, and heavy metals. Data collection will finish at the end of 1994.

4) assesses human health risks so far as they relate to the intake of fish. Based on data collection through 1994, tissues from resident fish (bass) and migrating fish (salmon) will be collected to determine potential human health risks. This work will be reported after June 1995.

5) assesses fish and wildlife habitats and risks. Specific ecological effects will be studied using tissue samples from mink, otter, bald eagles, and from fish. This work will be reported after June 1995.

\subsubsection{Jurenile Salmon Habitat}

The National Marine Fisheries Agency studied juvenile salmon habitat from 1965 through 1993. The study goal was to investigate changes in migration and survival of juvenile fish as a result of Columbia River draw-down. Some wildlife studies have also been conducted at and below the John Day Reservoir.

\subsection{Planned Data Collection}

Many of the programs described in Section 2.2 will continue to collect data in the future. This is noted in Table 1. In addition, several new proposed data collection activities were discovered during the data collection discussed previously. The following sections describe special studies that may be conducted in the future.

\subsubsection{U.S. Geological Survey}

The USGS may perform the following three studies:

- National Water Quality Assessment - an intensive study of the Columbia Basin that will sample pesticides and characterize several other chemicals. A contact is Stuart McKenzie, USGS, Portland.

- National Biological Survey - physical data will be collected to model spawning habits of (juvenile) fish and the effects of draw-down, for example, on the Snake and Columbia rivers. 
- In conjunction with the National Biological Survey, may perform 3-dimensional water temperature monitoring on the Snake and Columbia rivers. The study would determine how fish respond to changes in temperature and water volume as a result of reservoir draw-down.

\subsubsection{National Marine Fisheries Agency}

The National Marine Fisheries Agency's Point Adams Biological Field Station is proposing long-term collection of physical, chemical, and biological data for the lower Columbia River. Emphasis would be on limnology, benthic organisms, zooplankton, and water quality. The goal is to provide baseline information to detect long-term perturbations in the river, with the capability to note changes associated even with drought and other major climate changes.

\subsubsection{Agency for Toxic Substances and Disease Registry}

The goal for the Agency for Toxic Substances and Disease Registry (ATSDR) is to perform health risk assessments in areas of concern and to perform follow-up evaluations, health, and epidemiology studies where necessary. An ATSDR assessment reviews available contaminant concentrations and exposure pathways to determine whether exposures are significant enough to trigger adverse health effects. When the probabililty of risk is present, ATSDR may collect clinical samples. ATSDR/CDC risk assessment deals with public health, whereas EPA risk assessment focuses on the need for remedial action and the cleanliness of a site.

Currently the ATSDR is participating in a health assessment study for the 1100 Area at at the Hanford Site (Project Officer: Joanne Friedman, Atlanta, GA, 404-639-6068) with the Fred Hutchinsen Cancer Center in Seattle. They propose to study potential health risks: 1) at all four Hanford NPL sites, 2) associated with site-wide ground water contaminants, and 3) as they impact the Columbia River. In addition to risk assessments, ATSDR has organized an advisiory health council of native American and publically nominated members to incorporate their concerns into the direction of ATSDR/CDC health studies at Hanford. 
Table 2.1. Current and Future Columbia River Sampling Activities

\begin{tabular}{|c|c|c|c|c|c|}
\hline Project Name & $\begin{array}{c}\text { Funding Agency } \\
\text { (DOE, EPA, } \\
\text { Ecology, etc.) }\end{array}$ & $\begin{array}{c}\text { Organization } \\
\text { Collecting Data } \\
\end{array}$ & $\begin{array}{c}\text { Monitoring } \\
\text { (Current/Planned) }\end{array}$ & $\begin{array}{c}\text { Columbia River } \\
\text { Locations }\end{array}$ & $\begin{array}{c}\text { Data: Form, Location, } \\
\text { Availability }\end{array}$ \\
\hline $\begin{array}{l}\text { Surface Environmental } \\
\text { Surveillance Project }\end{array}$ & DOE-RL & $\begin{array}{l}\text { PNL (Surface } \\
\text { Monitoring } \\
\text { Project) }\end{array}$ & $\begin{array}{l}\text { Current: on-going } \\
\text { since } 1945\end{array}$ & $\begin{array}{l}\text { Priest Rapids Dam to } \\
\text { McNary Dam } \\
\text { (Hanford Reach) }\end{array}$ & $\begin{array}{l}\text { Annual Environmental } \\
\text { Report, for example: } \\
\text { PNL-8682 for } 1992\end{array}$ \\
\hline $\begin{array}{l}\text { Groundwater Environmental } \\
\text { Surveillance Project }\end{array}$ & DOE-RL & $\begin{array}{l}\text { PNL } \\
\text { (Groundwater } \\
\text { Monitoring } \\
\text { Project) }\end{array}$ & On-going & $\begin{array}{l}\text { Hanford Reach but } \\
\text { not the Columbia } \\
\text { River }\end{array}$ & $\begin{array}{l}\text { Annual Environmental } \\
\text { Report }\end{array}$ \\
\hline Salmon Census & $\begin{array}{l}\text { BPA/EPA } \\
\text { (CERCLA) }\end{array}$ & PNL & $\begin{array}{l}\text { Current: on-going } \\
\text { since } 1948\end{array}$ & Hanford Reach & $\begin{array}{l}\text { Periodic technical reports, } \\
\text { journal articles, and } \\
\text { presentations }\end{array}$ \\
\hline $\begin{array}{l}\text { Wildlife Resources: eagle, } \\
\text { goose census; salmon } \\
\text { spawning; riparian plant } \\
\text { species }\end{array}$ & DOE-RL & $\begin{array}{l}\text { PNL- Terrestrial } \\
\text { Ecology }\end{array}$ & Current: on-going & $\begin{array}{l}\text { Hanford Reach: } \\
\text { islands and riparian } \\
\text { areas }\end{array}$ & $\begin{array}{l}\text { Annual reporting and } \\
\text { technical publications }\end{array}$ \\
\hline $\begin{array}{l}100 \text { Area Operations } \\
\text { Environmental Monitoring }\end{array}$ & DOE-RL & Westinghouse & On-going & $\begin{array}{l}\text { Hanford Reach near } \\
100 \text { Areas }\end{array}$ & Annual reports \\
\hline $\begin{array}{l}100 \text { Area Operable Unit } \\
\text { Studies }\end{array}$ & DOE/EPA & Westinghouse & $\begin{array}{l}\text { Some limited field } \\
\text { investigations are } \\
\text { on-going for } F \\
\text { and } N \text { areas }\end{array}$ & $\begin{array}{l}\text { Hanford Reach in } 100 \\
\text { Areas }\end{array}$ & Westinghouse reports \\
\hline $\begin{array}{l}300 \text { Area Operable Unit } \\
\text { studies }\end{array}$ & DOE-RL & Westinghouse & $\begin{array}{l}\text { Ground water as } \\
\text { needed }\end{array}$ & $\begin{array}{l}\text { Ground water and } \\
\text { Columbia River water }\end{array}$ & $\begin{array}{l}\text { Remedial investigation or } \\
\text { feasibility study reports as } \\
\text { developed }\end{array}$ \\
\hline
\end{tabular}


Table 2.1. (contd)

\begin{tabular}{|c|c|c|c|c|c|}
\hline Project Name & $\begin{array}{c}\text { Funding Agency } \\
\text { (DOE, EPA, } \\
\text { Ecology, elc, } \\
\end{array}$ & $\begin{array}{c}\text { Organization } \\
\text { Collecting Data } \\
\end{array}$ & $\begin{array}{c}\text { Monitoring } \\
\text { (Current/Planned) }\end{array}$ & $\begin{array}{c}\begin{array}{c}\text { Columbia River } \\
\text { Locations }\end{array} \\
\end{array}$ & $\begin{array}{c}\text { Data: Form, Location, } \\
\text { Availability }\end{array}$ \\
\hline $\begin{array}{l}\text { NPDES Permits (Hanford } \\
\text { Site) }\end{array}$ & DOE-RL & $\begin{array}{l}\text { Westinghouse } \\
100 \text { and } 300 \\
\text { Areas }\end{array}$ & On-going & $\begin{array}{l}\text { At points of industrial } \\
\text { and municipal } \\
\text { discharge }\end{array}$ & Annual reports \\
\hline $\begin{array}{l}\text { NPDES Permits (Columbia } \\
\text { River) }\end{array}$ & $\begin{array}{l}\text { WA Ecology; OR } \\
\text { DEQ; EPA }\end{array}$ & 637 permits & On-going & $\begin{array}{l}\text { At points of industrial } \\
\text { and municipal } \\
\text { discharge }\end{array}$ & $\begin{array}{l}\text { WA and } O R \text { state agency } \\
\text { reports }\end{array}$ \\
\hline $\begin{array}{l}\text { Hanford Oversight, } \\
\text { Washington Department of } \\
\text { Ecology }\end{array}$ & $\begin{array}{l}\text { Washington Dept. of } \\
\text { Ecology }\end{array}$ & Ecology/DOE & On-going & Hanford Reach & Ecology reports \\
\hline $\begin{array}{l}\text { Drinking Water Quality and } \\
\text { River Quality, Hanford } \\
\text { Oversight, Washington } \\
\text { Department of Health }\end{array}$ & $\begin{array}{l}\text { Washington Dept. of } \\
\text { Health (oversight) }\end{array}$ & $\begin{array}{l}\text { WA Dept. of } \\
\text { Health }\end{array}$ & On-going & Benton County & e \\
\hline $\begin{array}{l}\text { Oregon State Health } \\
\text { Division, Radiation Control } \\
\text { Section }\end{array}$ & Oregon State Health & $\begin{array}{l}\text { Oregon State } \\
\text { Health }\end{array}$ & On-going & $\begin{array}{l}\text { Columbia River from } \\
\text { McNary Dam } \\
\text { downward }\end{array}$ & Toombs Reports \\
\hline $\begin{array}{l}\text { Radiological Environmental } \\
\text { Monitoring Program }\end{array}$ & $\begin{array}{l}\text { Washington Public } \\
\text { Power Supply } \\
\text { System }\end{array}$ & Power Supply & On-going & $\begin{array}{l}\text { Hanford Reach of } \\
\text { River in vicinity of } \\
\text { WPPSS }\end{array}$ & $\begin{array}{l}\text { Annual report for Nuclear } \\
\text { Plant } \# 2\end{array}$ \\
\hline
\end{tabular}


Table 2.1. (contd)

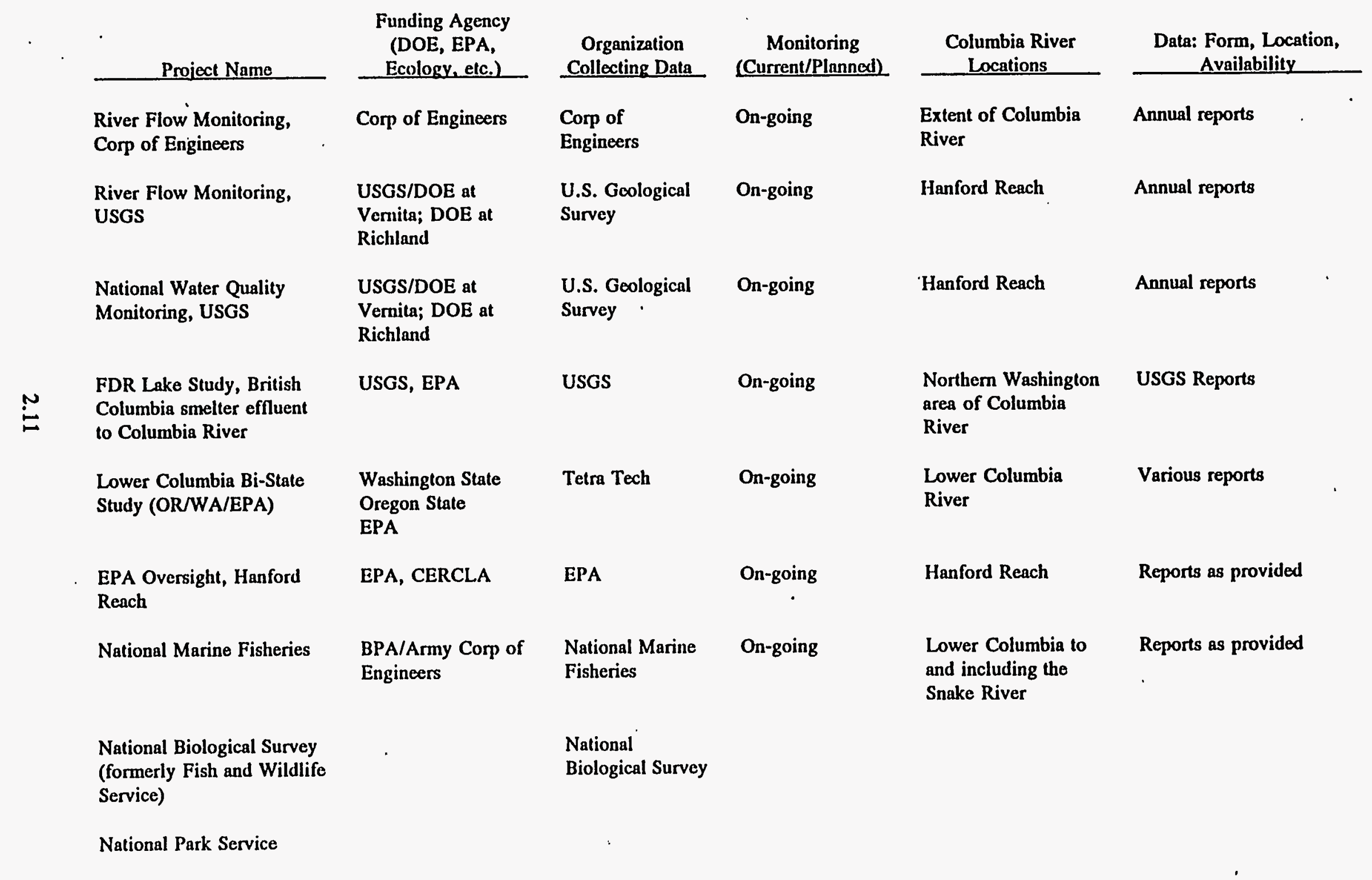


Table 2.1. (contd)

\begin{tabular}{|c|c|c|c|c|c|}
\hline Project Name & $\begin{array}{c}\text { Funding Agency } \\
\text { (DOE, EPA, } \\
\text { Ecology, etc.) }\end{array}$ & $\begin{array}{c}\text { Organization } \\
\text { Collectine Data } \\
\end{array}$ & $\begin{array}{c}\text { Monitoring } \\
\text { (Current/Planned) }\end{array}$ & $\begin{array}{c}\text { Columbia River } \\
\text { Locations }\end{array}$ & $\begin{array}{c}\text { Data: Form, Location } \\
\text { Availability } \\
\end{array}$ \\
\hline $\begin{array}{l}\text { Confederated Tribes of the } \\
\text { Umatilla Indian Reservation }\end{array}$ & DOE/CDC & $\begin{array}{l}\text { Confederated } \\
\text { Tribes }\end{array}$ & On-going & & Confederated Tribes \\
\hline $\begin{array}{l}\text { Columbia River Inter-Tribal } \\
\text { Fish Conmmission }\end{array}$ & DOE/CDC & $\begin{array}{l}\text { Confederated } \\
\text { Tribes }\end{array}$ & On-going & & Confederated Tribes \\
\hline
\end{tabular}

Note: Some cells are blank because the information has not been verified. 


\subsection{Search Process for Compendium Data}

This section describes the process used to support a comprehensive search for existing environmental data. Searches were divided into onsite and offsite sources of information. Many of the searches were performed electronically in databases of references. The keywords used for automated searches are given, and a summary of all searches conducted is provided. Reference information for documents identified in these searches was downloaded into a database developed by the CRCIA to manage the reference information.

In addition to reference information, the searches attempted to identify the document location. This location information is used to divide the references into two major sets, those already in the public domain (the DOE Reading Room in Richland), and those not in the DOE Reading Room but available to the public. The entire DOE Reading Room database, containing over 13,000 records, was loaded into the CRCIA project reference database. This database was used to identify documents already accessible to the public. If a copy of the document is in the DOE Reading Room, the document location will be identified as the DOE Reading Room, although copies may be found at other locations.

\subsection{Definition of Search Keywords}

Sets of keywords were developed for use in identifying information relevant to the CRCIA. These keywords are identified in this section. The parenthetical entries on some entries in the following keyword lists indicate alternative spellings or an expanded set of keywords under one topic.

\subsubsection{Onsite Search}

A basic set of keywords was used to identify the information that dealt specifically with Hanford. Other keywords were added to broaden the search. All searches were done on combinations of keywords and duplicate document references were removed before the reference was incorporated into the CRCIA reference database. The basic set of keywords are:

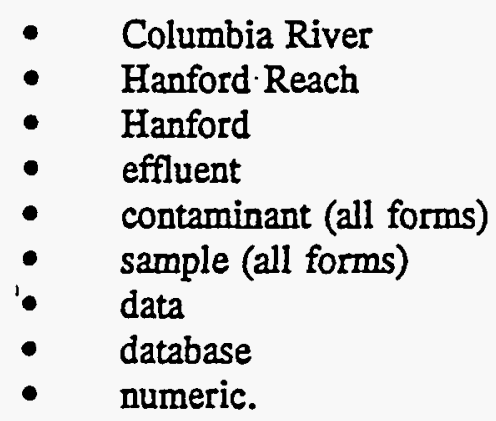


The search was enlarged with broader terms to include the keywords:

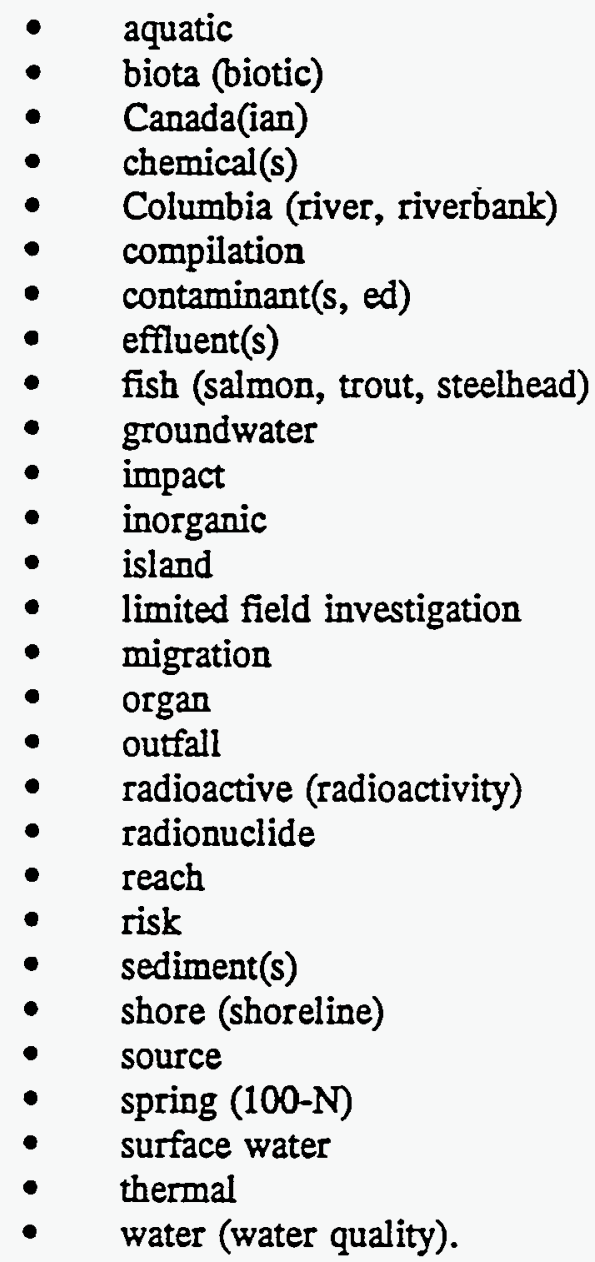

\subsubsection{Offsite Search}

The set of keywords for the onsite searches was modified for use in identifying information from offsite sources. These searches dropped the keyword Hanford and Hanford Reach from the onsite list, and added keywords meant to identify mining, other industrial, and agricultural uses of the river. Keywords used to specify general topics of interest are:

- water quality database

- in-stream sampling

- nonpoint source pollution

- point source pollution

- pollution assessment

- discharge

- dredge disposal

- estuaries

- $\quad$ environmental studies 
- water chemistry (carbon dioxide, fluoride, monitoring methods, nitrogen, oxygen, particulate carbon, phosphorus, salinity)

- oil.

Keywords used to identify mining uses of the river are:

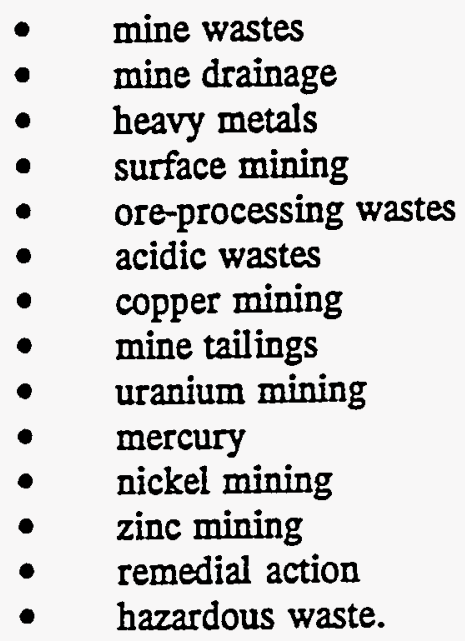

Keywords used to identify other industrial uses and agricultural uses of the river are:

- sawmill wastes

- paper mill wastes

- pulp mill wastes/sludge

- vermiculite refining

- phosphate/phosphate operations

- fertilizers.

Miscellaneous keywords used to identify contaminant information are:

- bacterial contamination

- septic tank effluent

- pesticides

- herbicides

- toxic wastes

- dioxin

- PCBs

- radioactive fallout

- radionuclides

- radiological

- radioactivity detection

- removal of radioactivity

- $\mathrm{pH}$

- effects of pollution

- $\quad$ sediment

- $\quad$ sediment composition analysis 
- $\quad$ suspended sediment

- $\quad$ sediment transport.

Keywords used to include information about the major tributaries of the Columbia River are:

- Yakima River Basin

- Spokane River Basin

- Okanogan River Basin

- Snake River Basin

- Umatilla River

- Deschutes River

- Willamette River.

\subsection{Summary of Searches}

The information searches performed for the CRCIA were divided into onsite and offsite searches. Almost all onsite searches involved sources that were funded by DOE. Almost all offsite searches involved non-DOE sources of information.

\subsubsection{Onsite Searches}

Numerous searches were executed for onsite information sources. Many computerized cataloging systems are available for onsite information repositories. Where possible, keyword searches were performed electronically, using the keywords defined above.

\subsubsection{DOE Reading Room, Richland, Washington}

The DOE Reading Room database is a focal point for the data gathering effort on the Data Compendium. A keyword search using the words Columbia River was initiated with 478 documents listed. A complete keyword search resulted in thousands of entries.

\subsubsection{Hanford Technical Library}

A comprehensive search was conducted at the Hanford Technical Library using the keywords identified previously. The following files and databases were searched:

\footnotetext{
- Energy Science Technologies 1974-1994 (Dialog Info. Services.)

- Nuclear Science Abstracts 1948-1976 (Dialog Info. Services.)

- INSPEC 1969-1994 (Institution of Electrical Engineers)

- Ei Compendex*Plus 1970-1994 (Engineering Info.)

- NTIS 1964-1994 (National Technical Info. Services.)

- Water Resources Abstracts (Dialog Info Services.)

- Enviroline 1970-1993 (CIS, Inc.)

- Env. Bib. 1974-1993 (Environmental Bibliographies)

- Energyline 1970-1993 (CIS, Inc.)

- WATERNET 1971-1993 (American Water Works Assoc.)
} 
- Aquatic Sci. \& Fisheries Abs. (Cambridge Science Abstracts)

- FLUIDEX 1973-1994

- GeoRef 1785-1994 (American Geological Institute)

- GEOBASE 1980-1994 (Elsevier Science Ltd.)

- BIOSIS Previews 1969-1994 (BIOSIS)

- CA Search 1967-1993 (American Chemical Society)

\subsubsection{Hanford Technical Reports}

A keyword search was conducted with the Hanford Technical Reports database. The Information Resource Tracking System master database used for the HEDR Project data gathering effort was obtained in both electronic and paper forms. Each of these 7000 records was added to the CRCIA reference database, but only if it was not a duplicate of an existing reference.

Over 650 declassified titles of documents were recently made available by DOE. These titles are included in Appendix B. In addition, 12 documents relating to historical studies of the Yakima River have been released.

The DOE contract allows Battelle, Pacific Northwest Laboratories (BNW) to conduct private business in addition to government business. Reports have been generated from privately-funded projects at BNW that contain information related to the health of the Columbia River. These nonDOE products become the property of the funding organization. A request will be made to the sponsoring agency for release approval when such private work, that may be relevant to the CRCIA, is identified.

\subsubsection{Environmental Restoration Program Information Center}

To ensure proper focus on Columbia River, a massive keyword search was executed. The Environmental Restoration Program Information Center includes multiple databases relating to Westinghouse Hanford Company and all preceding maintenance and operations contractors on the Hanford Site. The databases that were searched for the compendium are the Environmental Data Management Center and the Basalt Waste Isolation Project. More than 30,000 records were searched. This included letters and memos with and without attachments. Sampling data was also included in the search.

\subsubsection{Administrative Record Center}

The Administrative Record Center is operated for DOE to house all TPA documents that are in the public review process. This center is part of the Environmental Restoration Program Information Center. A keyword search was also executed on documents in the Administrative Record Center. Documents maintained there are transferred to the DOE Reading Room. A small number of documents were identified that are in the public review, comment, and transfer to the DOE Reading Room process.

\subsubsection{Westinghouse Central Files}

Westinghouse Central Files maintains records of all DOE and Westinghouse Hanford Company documents that are produced. A keyword search was conducted on all information that is electronically available. 
A search was conducted of historical documents (1987 and earlier) related to past management and operations contractors (United Nuclear Inc., Douglas United Nuclear, ISOCHEM, General Electric, du Pont, and Atlantic-Richfield Hanford Company). Between 5000 and 10,000 card catalog entries of these historical documents are not in any electronic reference database. A spot check search was conducted on these documents. Approximately 2500 cards were examined and about 50 references were gathered as a result.

\subsubsection{NPDES Permits}

The DOE maintains an National Pollutant Discharge Elimination System (NPDES) permit issued by the EPA for up to eight nonradioactive discharge points on the Hanford Site. Two of these points are at the $100 \mathrm{~K}$ Area, five are at the $100 \mathrm{~N} \mathrm{Area}$, and one is at the 300 Area.

\subsubsection{DOE Records Holding Area}

The DOE maintains a records holding area at Hanford that contains records from most projects conducted on the Hanford site. These records contain such items as: project log books, notebooks, correspondence, lab results, and reports to clients. These records are mostly stored in boxes, with little information being kept on the contents of each box. When space is required, the boxes are transferred to a federal storage facility in Seattle. The Hanford records holding center contains about 40,000 boxes of records, and the Seattle Records Holding Area contains over 500,000 boxes.

No search for information was made in the records holding area. Over the last seven years the Technical Steering Panel (TSP) for the HEDR project has conducted random physical searches of the records in the Seattle storage facility. Panel members were interested in obtaining information to assist in estimating the amount of radioactive materials released from Hanford from 1944 through 1992. Dr. B. Shleien of the TSP is currently preparing an annotated bibliography of documents reviewed for the HEDR project. Based on the search by the TSP, and the fact that monitoring programs are currently being conducted, no data located in a new search of the records holding area is expected to change the conclusions reached in a study concerned with current impacts of past and current releases.

\subsubsection{Washington Public Power Supply System}

The WPPSS maintains an information center that was searched electronically. The WPPSS facility contains over 500,000 entries. Only a few documents of interest were located.

\subsubsection{Offsite Searches}

After leaving Canada, the mainstem Columbia River flows only through the states of Washington and Oregon, and the potential for Columbia River water use is within those state boundaries. Other states would not be expected to possess or maintain large databases of Columbia River data, but may posses databases for tributary systems. The Snake River, the largest tributary system of the Columbia River, drains most of Idaho, which includes the Idaho National Engineering Laboratory, and a portion of western Montana. 
Laboratory, and a portion of western Montana.

The most complete historical offsite monitoring databases for the Columbia River below Hanford are from the state health agencies of Washington and Oregon. The monitoring continues on an annual basis, but the amount of data is limited to radionuclides and locations of specific interest. The state universities do not maintain any databases, but do retain reports of various river and coastal research studies. The USGS maintains a river gauging database that includes some water quality measurements. This database is publicly available through their agency offices or the commerciallyavailable EARTHINFO computerized system.

\subsubsection{Hanford Technical Library}

The initial offsite data search was conducted with assistance from staff at the Hanford Technical Library. The keyword list did not include the word Hanford or other words specific to the Hanford Site. However, words such as radiological, radioactive fallout, and radionuclide were included. The word list focused on words associated with the mining and paper mill industries and the use of agricultural chemicals. Words that are unique to river water quality data collection programs were included. A separate string of key words identified seven primary tributary systems of the Columbia River.

The search was begun by scanning 16 reference material data files considering only the words Columbia River. Using those results, other key words were systematically included in the search, except for the seven river basin names. Upon completion of the keyword search (minus the river basins), a separate search was conducted for each river basin. All duplicate records were omitted in the final listing. Other efforts will be directed toward reviewing the search results and expanding the offsite river databases.

Data files included in the Hanford Technical Library search were:

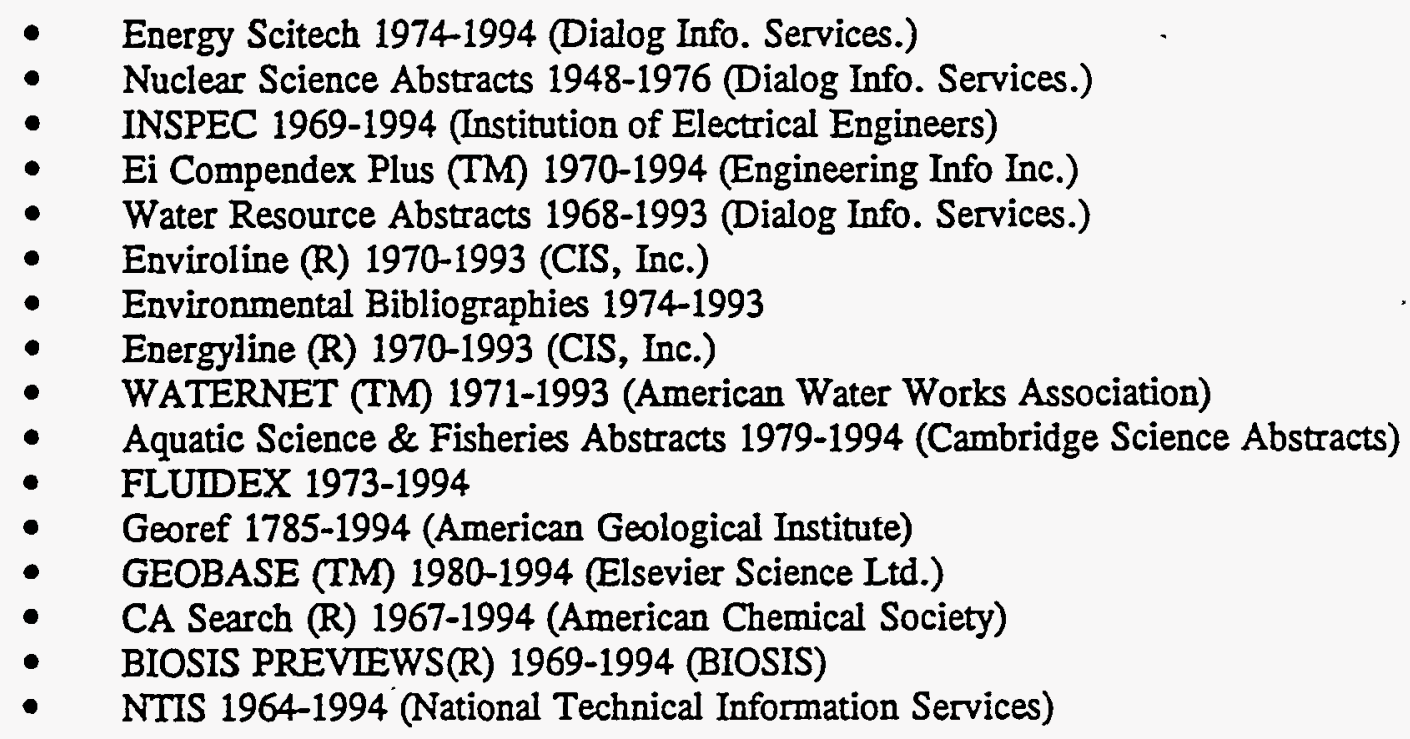




\subsubsection{NPDES Permits Not at Hanford}

The Washington State Department of Ecology provided a list of all (excluding the northwest region of the state and Puget Sound) NPDES permits issued in the State of Washington. Discharge data may be requested for any of the permitted discharge points. The listing includes municipal, commercial, and industrial operations. A list was also provided for state-issued waste water permits. A total of 637 NPDES discharge sites are located in the State of Washington.

Information on the NPDES permits for Oregon was not readily available at the time this document was written. The information is still being sought.

\subsubsection{City of Richland, Water Quality Department}

The City of Richland monitors the Columbia River water after intake. Monitoring prior to and at intake is accomplished by WPPSS, Washington State Department of Health, and PNL. The PNL data is available annually in the Site Environmental Report (Woodruff and Hanf, 1993).

\subsubsection{American Waterworks Association}

Within the past five years, the American Waterworks Association's national office in Denver, Colorado completed a comprehensive river study at the city water intake area.

\subsubsection{State of Washington, Division of Social and Health Services}

The State of Washington has an Environmental Radiation Program within the Division of Social and Health Services. This program performs radiological surveillance. Between 1961 and 1962, gross gamma and gross beta were monitored, but no specific radionuclides. From 1969 through 1976, the program published five reports (1970, 1972, 1974, 1975, 1976) where zinc-65, chromium-51, phosphorus-32, and scandium-46 were monitored in the Columbia River and on the Washington coast in clams, oysters, and crabs. Between 1977 and 1987, water and sediment samples were taken to monitor tritium and strontium-90 near Hanford and in the vicinity of the Trojan Nuclear Plant.

\subsubsection{University of Washington}

The Laboratory of Water Quality and Radiation Ecology and the Fisheries-Oceanography Library are the main information repositories at the University of Washington. The FisheriesOceanography Library catalog is available on INTERNET. Data available from these sources are in reports published from 1960 through 1970. These reports document efforts to monitor water, sediment, and several biota species for zinc-65, chromium-51, phosphorus-32, scandium 46 , and potassium 40 . These monitoring efforts were performed in coastal Washington (North Head; Willapa Bay; Hood Canal) and in Oregon. The water and sediment samples supported analysis of: zinc-65 and chromium-51 in plankton, zinc-65 in Willapa Bay oysters, and phosphorus-32 in clams, mussels, barnacles, anemones, and algae. 


\subsubsection{State of Oregon, Department of Human Resources}

The Health Division of the Department of Human Resources for the State of Oregon has performed radionuclide monitoring since 1961. A study of the Columbia River and coastal locations (1961 through 1977) involved monitoring water, sediment, and biota for 10 radionuclides. Zinc-65, chromium-51, and phosphorus-32 are of special interest. A study of the Columbia River and major tributaries (1961 through 1983) involved the Columbia, Snake, Willamette, Klamath, and coastal rivers. Water, sediment, and algae were monitored for gross alpha, gross beta, tritium, phosphorus32, zinc-65, and chromium-51. A recent study of the Columbia River and tributaries (1984 through 1992) considered data from the Columbia, Deschutes, John Day, Umatilla, and Grande Ronde Rivers. The radionuclides monitored were gross alpha, gross beta, tritium, potassium-40, radium-226, beryllium-7, and thorium-232.

\subsubsection{Oregon State University}

The campus library at Oregon State University in Corvallis, Oregon maintains references from the School of Oceanography. The university also operates the Sciences Laboratory at Newport, OR. No large, comprehensive databases are housed there, but data are available in small quantities in individual reports. These reports describe monitoring in estuary and coastal locations. Zinc- 65 and chromium-51 are key radionuclides. The biota monitored are tuna, salmon, shellfish, sediment, water, crab, flounder, and benthic marine life.

\subsubsection{U.S. Geological Survey.}

The products of the USGS include USGS professional papers that give sampling results from early to mid-1960s. Samples were taken from Pasco, Washington to Vancouver, Washington for water and sediment only. The radionuclides included were zinc-65, chromium-51, manganese-54, scandium -46 , and cobalt -60 .

\subsubsection{EARTHINFO Inc.}

This Denver, Colorado company maintains monitoring data for the Columbia River and all gauged tributaries. Information included is water discharge and stage, and water quality data (only that measured by USGS). This information is updated annually.

\subsubsection{Pacific Northwest River Basin Commission}

The Pacific Northwest River Basin Commission in Vancouver, Washington, runs the Columbia River Estuary Data Development Program. Information available includes maps and channel geometry data of Columbia River estuary, and numerous reports with small data listings for water, sediment, and biota.

\subsubsection{U.S. Department of Health, Education, and Welfare}

The U.S. Department of Health, Education and Welfare (HEW) Public Health Service monitored the Columbia River from Priest Rapids Dam to Paterson, Washington, in 1951 through 1953. This effort included monitoring gross beta activity in water, sediment, and biota. 


\subsection{Results}

\subsection{Results of the Compendium Data Search}

The search for radiological and nonradiological contaminant data identified approximately 4500 documents and 13 major databases that potentially contain information about contaminants in the Columbia River that are due to activities on the Hanford Site. As described previously, searches for data were conducted electronically, through phone calls, and with personal visits.

\subsubsection{Database Identification}

A total of 13 major databases were identified in the data search as containing information on contaminants in the Columbia River. A short discussion of these databases is included in Appendix C. All of the databases are available from the database custodian, or are being made available to EPA and Ecology through the TPA process.

\subsubsection{Unpublished Information}

During the search for data, some data and documents were identified that have never been published in any form. These data include:

- Sampling data on the Columbia River collected by George Toombs, Oregon Department of Health

- Many of the data in the Northwest Environmental Database (NED) are not described in any document and are not readily available through other avenues.

- The PNL document clearance system contains drafts of a number of documents that were never completed. This system will be searched for draft document information pertaining to contaminants in the river.

- The WHC document clearance system also contains drafts of a number of documents that were never completed. This system will be searched for draft documents information pertaining to contaminants in the river.

\subsubsection{Published Information That is Publicly Available}

Approximately 1750 of the documents identified in the search process are already available to DOE, Ecology, EPA, and the public. That is, the document is available at the DOE Reading Room. References for these documents are given in electronic format in Appendix D.

\subsubsection{Documents Not Publicly Available}

Approximately 2050 of the documents identified in the search process were not readily available to members of the public. References for these documents are given in electronic format in Appendix A. 


\subsubsection{Formerly Classified Titles}

Recently, more than 650 declassified titles of classified documents were made available by DOE. Even though the titles were declassified, many of the documents remain classified. The titles of these documents are provided in Appendix B.

Several of these documents appear to contain information relating to historical releases of contaminants to the Columbia River. The documents written before 1980 are probably of interest more for reconstructing past releases than for examining current conditions.

\subsection{Key Documents}

The search process for information on contaminants in the Columbia River has identified approximately 4500 documents that potentially contain information about contaminants in the Columbia River due to activities on the Hanford Site. It would be a monumental task for any one person to read all of these documents. Therefore, two abbreviated document reference lists are provided in this section. These reference lists identify documents containing key information for conducting an analysis of ecological and human health impacts from contaminants currently in the Columbia River.

The first list contains one or two documents in several data collection and analysis areas. These documents are also contained in the second list. The areas and documents are:

- Environmental monitoring:

Woodruff R. K. and R. W. Hanf (eds). 1993. Hanford Site Environmental Report 1993. PNL-8682. Pacific Northwest Laboratory. Richland, Washington.

- Historical release of radionuclides:

Heeb, C. M. and D. J. Bates. 1994. Radionuclide Releases to the Columbia River from Hanford Operations, 1944-1971. PNWD-2223 HEDR. Battelle, Pacific

Northwest Laboratories. Richland, Washington.

- Human health analyses:

Farris, W. T., B. A. Napier, J. C. Simpson, S. F. Snyder, and D. B. Shipler. -1994. Columbia River Pathway Dosimetry Report, 1944-1992. PNWD-2227 HEDR Draft, Battelle, Pacific Northwest Laboratories. Richland, Washington.

Wells, D. 1994. Radioactivity in Columbia River Sediments and Their Health Effects. Washington State Department of Health. Olympia, Washington. 
- Ground water-based releases to the river:

U.S. Department of Energy. 1994. Annual Report for RCRA Groundwater

Monitoring Projects at Hanford Site Facilities for 1993. DOE/RL-93-88 Rev. 0.

United States Department of Energy - Richland Operations Office. Richland,

Washington.

- Ecological assessments:

Becker, C. D. 1990. Aquatic Bioenvironmental Studies: The Hanford Experience 1944-84. Pacific Northwest Laboratory. Elsevier Science Publishing Company Inc. New York, New York.

Friant, S. L. and C. A. Brandt. 1993. Ecological Risk Assessment of Radionuclides in the Columbia River System "A Historical Assessment". PNL-8293. Pacific Northwest Laboratory. Richland, Washington.

- River modeling:

Walters, W. H., M. C. Richmond, and B. G. Gilmore. 1994. PNWD-2225 HEDR. Reconstruction of Radionuclide Concentrations in the Columbia River from Hanford. Washington te Portland, Qregon January 1950 - January 1971. Battelle, Pacific Northwest Laboratories. Richland, Washington.

The second abbreviated list of documents is much more extensive. However, no claim is made that this list identifies all of the important source documents for the CRCLA. A decision was made, somewhat arbitrarily, that this list of key documents would contain no more than 60 entries. Then, general selection criteria were established for including documents on the list. The criteria included the following considerations:

- Historical information would be included to ensure that a complete list of contaminants potentially of concern could be generated.

- Information was needed upstream and downstream of Hanford, as well as in the Hanford Reach of the Columbia River.

- Summary analyses would be included to help the reader find more obscure publications containing extensive discussions of the data or data collection processes.

- Information on metals and hazardous substances was needed in addition to information on radioactive materials.

- Published analyses for both ecological risk and human risk would be included.

- Information from funding sources other than the DOE would be included.

- The most recent information available would be included. 
The list of key documents has been divided into several subsections for ease of presentation. The subsection titles identify the general category or source of information.

\subsubsection{General and Historical Documents}

Becker, C. D. and R. H. Gray. 1989. Abstracted Publications Related to the Hanford Environment, 1980 to 1988. PNL-6905. Pacific Northwest Laboratory. Richland, Washington.

Becker, C. D. and R. H. Gray. 1992. "Past and Present Water-Quality Conditions in the Hanford Reach, Columbia River." Environmental Monitoring and Assessment, Vol. 22, pp. 137-152. Kluwer Academic Publishers, the Netherlands.

Farris, W. T., B. A. Napier, J. C. Simpson, S. F. Snyder, and D. B. Shipler. 1994. Columbia River Pathway Dosimetry Report, 1944-1992. PNWD-2227 HEDR, Battelle, Pacific Northwest Laboratories. Richland, Washington.

Gray, R. H. 1994. Hanford Environmental Publications/Presentations 1989-1993. Pacific Northwest Laboratory. Richland, Washington.

Robeck, G. G., C. Henderson, R. C. Palange. 1954. Water Quality Studies on the Columbia River. U.S. Department of Health, Education, and Welfare; Public Health Service, Division of Sanitary Engineering Services, Robert A. Taft Sanitary Engineering Center, Cincinnati, Ohio.

Thiede, M. E., D. J. Bates, E. I. Mart, and R. W. Hanf. 1994. A Guide to Environmental Monitoring Data, 1945-1972. PNWD-2226 HEDR. Battelle, Pacific Northwest Laboratories. Richland, Washington.

Woodruff, R. K. and R. W. Hanf (eds). 1992. Hanford Site Environmental Report 1992. PNL8682. Pacific Northwest Laboratory. Richland, Washington.

\subsubsection{Documents on Aquatic Ecology}

Becker, C. D. 1990. Aquatic Bioenvironmental Studies: The Hanford Experience 1944-84. Pacific Northwest Laboratory. Elsevier Science Publishing Company Inc. New York, New York.

Cushing, C. E. (ed.) 1991. Hanford Site National Environmental Policy Act (NEPA)

Characterization. PNL-6415, Rev. 4. Pacific Northwest Laboratory. Richland, Washington.

Cushing, C. E. 1993. Aquatic Studies at the 100-HR-3 and 100-NR-1 Operable Units. PNL-8584. Pacific Northwest Laboratory. Richland, Washington.

Dauble, D. D and D. G. Watson. 1990. Spawning and Abundance of Fall Chinook Salmon (Oncorhynchus tshawytscha) in the Hanford Reach of the Columbia River, 1948-1988. PNL-7289. Pacific Northwest Laboratory. Richland, Washington. 
Fickeisen, D. H., D. D. Dauble, D. A. Neitzel, W. H. Rickard, R. L. Skaggs, and J. L. Warren. 1980. Aquatic and Riparian Resource Study of the Hanford Reach. Columbia River. Washington. U.S. Army Corps of Engineers. Seattle, Washington.

Keenan, R. E., A. H. Parsons, E. S. Ebert, P. D. Boardman, S. L. Huntley, and M. M. Sauer. 1990. Assessment of the Human Health Risks Related to the Presence of Dioxins in Columbia River Fish. ChemRisk ${ }^{\pi x}$. A McLaren Company. Portland, Maine.

Page, T. L., D. D. Dauble, and D. A. Neitzel. 1982. Columbia River Aquatic Ecological Studies Near the Skagit/Hanford Nuclear Project: Final Report. Northwest Energy Services Company. Kirkland, Washington.

\subsubsection{Documents on General River Monitoring}

Antonio, E. J., T. M. Poston, and W. H. Rickard, Jr. 1993. Radiological Survey of Shoreline Vegetation from the Hanford Reach of the Columbia River, 1990-1992. PNL-8797. Pacific Northwest Laboratory. Richland, Washington.

Cooper, A. T. and R. K. Woodruff. 1993. Investigation of Exposure Rates and Radionuclide and Trace Metal Distributions Along the Hanford Reach of the Columbia River. PNL-8789. Pacific Northwest Laboratory. Richland, Washington.

Dirkes, R. L. 1990. 1988 Hanford Riverbank Springs Characterization Report. PNL-7500. Pacific Northwest Laboratory. Richland, Washington.

Dirkes, R. L. 1993. Columbia River Monitoring: Distribution of Tritium in Columbia River Water at the Richland Pumphouse. PNL-8531. Pacific Northwest Laboratory. Richland, Washington.

Dirkes, R. L., G. W. Patton, and B. L. Tiller. 1993. Columbia River Monitoring: Summary of Chemical Monitoring Along Cross Sections at Vernita Bridge and Richland. PNL-8654. Pacific Northwest Laboratory. Richland, Washington.

Dirkes, R. L. 1994. Summary of Radiological Monitoring of Columbia River Water Along the Hanford Reach, 1980 Through 1989. PNL-9223. Pacific Northwest Laboratory. Richland, Washington.

Haushild, W. L., G. R. Dempster, Jr., and H. H. Stevens, Jr. 1975. Distribution of Radionuclides in the Columbia River Streambed. Hanford Reservation to Longview, Washington. U.S. Department of the Interior in cooperation with the U.S. Atomic Energy Commission. U.S. Government Printing Office, Washington, D.C.

Heeb, C. M. and D. J. Bates. 1994. Radionuclide Releases to the Columbia River from Hanford Operations, 1944-1971. PNWD-2223 HEDR. Battelle, Pacific Northwest Laboratories. Richland, Washington. 
Hubbell, D. W. and J. L. Glenn. 1973. Distribution of Radionuclides in Bottom Sediments of the Columbia River Estuary. U.S. Department of the Interior in cooperation with the U.S. Atomic Energy Commission. U.S. Government Printing Office, Washington, D.C.

Hulstrom, L. C. 1993. Sampling and Analysis of the 300-FF-5 Operable Unit Springs, Nearshore Sediments and River Water, WHC-SD-EN-TI-125, Rev. 0, Westinghouse Hanford Company.

Pruter, A. T. and D. L. Alervson (eds). 1972. The Columbia River Estuary and Adjacent Qcean Waters: Bioenvironmental Studies. United States Atomic Energy Commission. University of Washington Press.

Walters, W. H., R. L. Dirkes, and B. A. Napier. 1992. Literature and Data Review for the Surface-Water Pathway: Columbia River and Adjacent Coastal Areas. PNWD-2034 HEDR. Battelle, Pacific Northwest Laboratories. Richland, Washington.

Walters, W. H., M. C. Richmond, and B. G. Gilmore. 1994. PNWD-2225 HEDR. Reconstruction of Radionuclide Concentrations in the Columbia River from Hanford, Washington to Portland, Oregon January 1950 - January 1971. Battelle, Pacific Northwest Laboratories. Richland, Washington.

\subsubsection{Documents on Ecological Assessments}

Friant, S. L. and C. A. Brandt. 1993. Ecological Risk Assessment of Radionuclides in the Columbia River System "A Historical Assessment". PNL-8293. Pacific Northwest Laboratory. Richland, Washington.

Rickard, W. H., L. E. Rogers, B. E. Vaughan, and S. F. Liebetrau (eds). 1988. shrub-steppe: balance and change in a semi-arid terrestrial ecosystem. Pacific Northwest Laboratory. Richland, Washington.

Thiede, M. E. and J. P. Duncan. 1994. Database of Radionuclide Measurements in Columbia River Water, Fish, Waterfowl, Gamebirds, and Shellfish Downstream of Hanford's Single-Pass Production Reactors, 1960-1970. PNWD-2242 HEDR. Battelle, Pacific Northwest Laboratories. Richland, Washington.

\subsubsection{Site Environmental Monitoring and Field Investigations}

Brandt, C. A., C. E. Cushing, W. H. Rickard, N. A. Cadoret, and R. Mazaika. 1993. Biological Resources of the 300-FF-5 Operable Unit. WHC-SD-EN-TI-121 Rev. 0. Westinghouse Hanford Company. Richland, Washington.

Brandt, C. A., C. E. Cushing, W. H. Rickard, N. A. Cadoret, R. Mazaika, and B. L. Tiller. 1993. Biological Uptake of 300-FF-5 Operable Unit Contaminants. WHC-SD-EN-TI-122 Rev. 0.

Westinghouse Hanford Company. Richland, Washington. 
Fitzner, R. E. and R. H. Gray. 1991. "The Status, Distribution and Ecology of Wildlife on the U.S. DOE Hanford Site: A Historical Overview of Research Activities". Environmental Monitoring and Assessment, Vol. 18, pp. 173-202. Kluwer Academic Publishers, the Netherlands.

Landeen, D. S., M. R. Sackschewsky, and S. G. Weiss. 1993. 100 Areas CERCLA Ecological Investigations. WHC-EP-0620. Westinghouse Hanford Company. Richland, Washington.

Manley, C. L. 1992. Environmental Releases for Calendar Year 1991. WHC-EP-0527-1. Westinghouse Hanford Company. Richland, Washington.

Perkins, C. J. 1989. Characterization of Radionuclide Concentrations Along the N-Springs Shoreline for 1988. WHC-SP-0480. Westinghouse Hanford Company. Richland, Washington.

Peterson, R. E. and V. G. Johnson. 1992. Riverbank Seepage of Groundwater Along the 100 Areas Shoreline, Hanford Site. WHC-EP-0609. Westinghouse Hanford Company. Richland, Washington.

Roeck, F. V. 1992. 100 Areas Hanford Past-Practice Site Cleanup and Restoration Conceptual Study. WHC-EP-0457. Westinghouse Hanford Company. Richland, Washington.

Rokkan, D. J. 1990. Westinghouse Hanford Company 100 Areas Environmental Releases for 1989. WHC-EP-0165-2. Westinghouse Hanford Company. Richland, Washington.

Schmidt, J. W., A. R. Johnson, S. M. McKinney, and C. J. Perkins. 1993. Westinghouse Hanford Company Operational Environmental Monitoring Annual Report, CY 1992. WHC-EP-0573-1. Westinghouse Hanford Company. Richland, Washington.

Thompson, K. M. 1991. Hanford Past-Practice Strategy. DOE/RL-91-40 Rev. 0. United States Department of Energy - Richland Operations Office. Richland, Washington.

U.S. Department of Energy. 1988. 316(a) Demonstration for Operation of N Reactor in DualPurpose Mode. United States Department of Energy - Richland Operations Office. Richland, Washington.

U.S. Department of Energy.. 1992. Sampling and Analysis of 100 Area Springs. DOE/RL-92-12 Rev. 1. United States Department of Energy - Richland Operations Office. Richland, Washington.

U.S. Department of Energy. 1992. Hanford Site Groundwater Background. DOE/RL-92-23 United States Department of Energy - Richland Operations Office. Richland, Washington.

U.S. Department of Energy. 1993. Limited Field Investigation Report for the 100-KR-4 Operable Unit. DOE/RL-93-79. United States Department of Energy - Richland Operations Office. Richland, Washington.

U.S. Department of Energy. 1993. Limited Field Investigation Report for the 100-BC-5 Operable Unit. DOE/RL-93-37 Draft A. United States Department of Energy - Richland Operations Office. Richland, Washington. 
U.S. Department of Energy. 1993. Columbia River Impact Evaluation Plan. DOE/RL-92-28

Rev. 0. United States Department of Energy - Richland Operations Office. Richland, Washington.

U.S. Department of Energy. 1994. Annual Report for RCRA Groundwater Monitoring Projects at Hanford Site Facilities for 1993. DOE/RL-93-88 Rev. 0. United States Department of Energy Richland Operations Office. Richland, Washington.

Weiss, S. G. and R. M. Mitchell. 1992. A Synthesis of Ecological Data from the 100 Areas of the Hanford Site. WHC-EP-0601. Westinghouse Hanford Company. Richland, Washington.

Weiss, S. G. 1993. 100 Area Columbia River Sediment Sampling. WHC-SD-EN-TI-198. Westinghouse Hanford Company. Richland, Washington.

\subsubsection{Documents from Non-Hanford Sources}

Johnson, A. and M. Heffner. 1993. Class II Inspection of the Boise Cascade Pulp and Paper Mill, Wallula, Washington - April 1992. Washington State Department of Ecology. Olympia, Washington.

Mah, F. T. S., D. D. MacDonald, S. W. Sheehan, T. M. Tuominen, and D. Valiela. 1989. Dioxins and Furans in Sediment and Fish from the Vicinity of Ten Inland Pulp Mills in British Columbia. Water Quality Branch Inland Waters Conservation and Protection Pacific and Yukon Region Environment Canada. Vancouver, B.C., Canada.

Oregon Department of Environmental Quality. 1992. Oregon's 1992 Water Quality Status Assessment Report 305 (b). Oregon Department of Environmental Quality. Portland, Oregon.

Oregon Department of Fish and Wildlife and Washington Department of Fisheries. 1993. Status Report Columbia River Fish Runs and Fisheries 1938-92. Oregon Department of Fish and Wildlife and Washington Department of Fisheries.

Serdar, D., A. Johnson, and S. Magoon. 1991. Polychlorinated Dioxins and - Furans in Columbia River Sportfish: Chief Joseph Dam to McNary Dam. Washington Department of Ecology. Olympia, Washington.

U.S. National Park Service. 1992. Hanford Reach of the Columbia River: Comprehensive River Conservation Study and Environmental. Impact Statement. DRAFT. U.S. National Park Service, Pacific Northwest Regional Office. Seattle, Washington.

Washington Public Power Supply System. 1978. Supplemental Information on the Hanford Generating Project in Support of a 316(a) Demonstration. Washington Public Power Supply System. Richland, Washington.

Washington Public Power Supply System. 1993. Radiological Environmental Monitoring Program. 1992 Annual Report for Nuclear Plant 2. Technical Specification 6.9.1.10. Washington Public Power Supply System. Richland, Washington. 
Washington State Department of Health. 1991. Washington State Environmental Radiation Program. 28th Annual Report January 1989-December 1989. Washington State Department of Health, Division of Radiation Protection, Environmental Radiation Section. Washington State Department of Health. Olympia, Washington.

Washington State Department of Health. 1993. Environmental Radiation Program 1921 Annual Report 30th Edition. Washington State Department of Health, Division of Radiation Protection, Environmental Radiation Section. Washington State Department of Health. Olympia, Washington.

Wells, D. 1994. Radioactivity in Columbia River Sediments and Their Health Effects. Washington State Department of Health. Olympia, Washington.

\subsubsection{Documents Being Transmitted to the DOE Reading Room}

A list of key documents on contaminants in the Columbia River was identified in Section 4.2. Approximately $50 \%$ of the documents on the list were not in the DOE Reading Room. Copies of these documents have been prepared and have been transmitted to the DOE Reading Room. The documents to be transmitted are divided into two categories:

- Books - a copy has been ordered for the DOE Reading Room,

- Reports - copies have been prepared.

\subsubsection{Books Ordered for the DOE Reading Room}

The following books have been ordered and will be transmitted to the DOE Reading Room in Richland when they are received from the publisher.

Becker, C. D. 1990. Aquatic Bioenvironmental Studies: The Hanford Experience 1944-84. Pacific Northwest Laboratory. Elsevier Science Publishing Company Inc. New York, New York.

Pruter, A. T. and D. L. Alervson (eds). 1972. The Columbia River Estuary and Adjacent Ocean Waters: Bioenvironmental Studies. United States Atomic Energy Commission. University of Washington Press.

Rickard, W. H., L. E. Rogers, B. E. Vaughan, and S. F. Liebetrau (eds). 1988. shrub-steppe: balance and change in a semi-arid terrestrial ecosystem. Pacific Northwest Laboratory. Richland, Washington.

\subsubsection{Reports Transmitted to the DOE Reading Room}

A copy of each of the following reports has been obtained and has been transmitted to the DOE Reading Room in Richland, Washington.

Antonio, E. J., T. M. Poston, and W. H. Rickard, Jr. 1993. Radiological Survey of Shoreline Vegetation from the Hanford Reach of the Columbia River, 1990-1992. PNL-8797. Pacific Northwest Laboratory. Rịchland, Washington. 
Becker, C. D. and R. H. Gray. 1992. "Past and Present Water-Quality Conditions in the Hanford Reach, Columbia River." Environmental Monitoring and Assessment, Vol. 22, pp. 137-152. Kluwer Academic Publishers, the Netherlands.

Brandt, C. A., C. E. Cushing, W. H. Rickard, N. A. Cadoret, and R. Mazaika. 1993. Biological Resources of the 300-FF-5 Operable Unit. WHC-SD-EN-TI-121 Rev. 0. Westinghouse Hanford Company. Richland, Washington.

Brandt, C. A., C. E. Cushing, W. H. Rickard, N. A. Cadoret, R. Mazaika, and B. L. Tiller.' 1993. Biological Uptake of 300-FF-5 Operable Unit Contaminants. WHC-SD-EN-TI-122 Rev. 0.

Westinghouse Hanford Company. Richland, Washington.

Cooper, A. T. and R. K. Woodruff. 1993. Investigation of Exposure Rates and Radionuclide and Trace Metal Distributions Along the Hanford Reach of the Columbia River. PNL-8789. Pacific Northwest Laboratory. Richland, Washington.

Cushing, C. E. 1993. Aquatic Studies at the 100-HR-3 and 100-NR-1 Operable Units. PNL-8584. Pacific Northwest Laboratory. Richland, Washington.

Fickeisen, D. H., D. D. Dauble, D. A. Neitzel, W. H. Rickard, R. L. Skaggs, and J. L. Warren. 1980. Aquatic and Riparian Resource Study of the Hanford Reach, Columbia River, Washington. U.S. Army Corps of Engineers. Seattle, Washington.

Fitzner, R. E. and R. H. Gray. 1991. "The Status, Distribution and Ecology of Wildlife on the U.S. DOE Hanford Site: A Historical Overview of Research Activities". Environmental Monitoring and Assessment, Vol. 18, pp. 173-202. Kluwer Academic Publishers, the Netherlands.

Friant, S. I. and C. A. Brandt. 1993. Ecological Risk Assessment of Radionuclides in the Columbia River System "A Historical Assessment". PNL-8293. Pacific Northwest Laboratory. Richland, Washington.

Gray, R. H. 1994. Hanford Environmental Publications/Presentations 1989-1993. Pacific Northwest Laboratory. Richland, Washington.

Haushild, W. L., G. R. Dempster, Jr., and H. H. Stevens, Jr. 1975. Distribution of Radionuclides in the Columbia River Streambed, Hanford Reservation to Longview. Washington. U.S. Department of the Interior in cooperation with the U.S. Atomic Energy Commission. U.S. Government Printing Office, Washington, D.C..

Hulstrom, L. C. 1993. Sampling and Analysis of the 300-FF-5 Operable Unit Springs, Nearshore Sediments and River Water, WHC-SD-EN-TI-125, Rev. 0, Westinghouse Hanford Company.

Johnson, A. and M. Heffner. 1993. Class II Inspection of the Boise Cascade Pulp and Paper Mill, Wallula. Washington - April 1992. Washington State Department of Ecology. Olympia, Washington. 
Keenan, R. E., A. H. Parsons, E. S. Ebert, P. D. Boardman, S. L. Huntley, and M. M. Sauer. 1990. Assessment of the Human Health Risks Related to the Presence of Dioxins in Columbia River Fish. ChemRisk ${ }^{\mathrm{x}}$.- A McLaren Company. Portland, Maine.

Landeen, D. S., M. R. Sackschewsky, and S. G. Weiss. 1993. 100 Areas CERCLA Ecological Investigations. WHC-EP-0620. Westinghouse Hanford Company. Richland, Washington.

Mah, F. T. S., D. D. MacDonald, S. W. Sheehan, T. M. Tuominen, and D. Valiela. 1989. Dioxins and Furans in Sediment and Fish from the Vicinity of Ten Inland Pulp Mills in British Columbia. Water Quality Branch Inland Waters Conservation and Protection Pacific and Yukon Region Environment Canada. Vancouver, B.C., Canada.

Oregon Department of Environmental Quality. 1992. Qregon's 1992 Water Quality Status Assessment Report 305 (b). Oregon Department of Environmental Quality. Porland, Oregon.

Oregon Department of Fish and Wildlife and Washington Department of Fisheries. 1993. Status Report Columbia River Fish Runs and Fisheries 1938-92. Oregon Department of Fish and Wildlife and Washington Department of Fisheries.

Page, T. L., D. D. Dauble, and D. A. Neitzel. 1982. Columbia River Aquatic Ecological Studies Near the Skagit/Hanford Nuclear Project: Final Report. Northwest Energy Services Company. Kirkland, Washington.

Perkins, C. J. 1989. Characterization of Radionuclide Concentrations Along the N-Springs Shoreline for 1988. WHC-SP-0480. Westinghouse Hanford Company. Richland, Washington.

Robeck, G. G., C. Henderson, R. C. Palange. 1954. Water Quality Studies on the Columbia River. U.S. Department of Health, Education, and Welfare; Public Health Service, Division of Sanitary Engineering Services, Robert A. Taft Sanitary Engineering Center, Cincinnati, Ohio.

Serdar, D., A. Johnson, and S. Magoon. 1991. Polychlorinated Dioxins and - Furans in Columbia River Sportfish: Chief Joseph Dam to McNary Dam. Washington Department of Ecology. Olympia, Washington.

U.S. Department of Energy. 1988. 316(a) Demonstration for Operation of N Reactor in DualPurpose Mode. United States Department of Energy - Richland Operations Office. Richland, Washington.

U.S. Department of Energy. 1992. Hanford Site Groundwater Background. DOE/RL-92-23 United States Department of Energy - Richland Operations Office. Richland, Washington.

U.S. Department of Energy. 1993. Limited Field Investigation Report for the 100-KR-4 Operable Unit. DOE/RL-93-79. United States Department of Energy - Richland Operations Office. Richland, Washington.

U.S. Department of Energy. 1993. Limited Field Investigation Report for the 100-BC-5 Operable Unit. DOE/RL-93-37 Draft A. United States Departiment of Energy - Richland Operations Office. Richland, Washington. 
U.S. Department of Energy. 1994. Annual Report for RCRA Groundwater Monitoring Projects at Hanford Site Facilities for 1993. DOE/RL-93-88 Rev. 0. United States Department of Energy Richland Operations Office. Richland, Washington.

Washington Public Power Supply System. 1978. Supplemental Information on the Hanford Generating Project in Support of a 316(a) Demonstration. Washington Public Power Supply System. Richland, Washington.

Washington Public Power Supply System. 1993. Radiological Environmental Monitoring Program. 1992 Annual Report for Nuclear Plant 2. Technical Specification 6.9.1.10. Washington Public Power Supply System. Richland, Washington.

Washington State Department of Health. 1991. Washington State Environmental Radiation Program, 28th Annual Report January 1989-December 1989. Washington State Department of Health, Division of Radiation Protection, Environmental Radiation Section. Washington State Department of Health. Olympia, Washington.

Washington State Department of Health. 1993. Environmental Radiation Program 1991 Annual Report 30th Edition. Washington Department of Health, Division of Radiation Protection, Environmental Radiation Section. Washington State Department of Health. Olympia, Washington.

Wells, D. 1994. Radioactivity in Columbia River Sediments and Their Health Effects. Washington State Department of Health. Olympia, Washington.

Westinghouse Hanford Company. 1993. 100 Area Columbia River Sediment Sampling. WHC-SDEN-TI-198. Westinghouse Hanford Company. Richland, Washington. 


\subsection{Future Activities in Data Management}

The data compendium in this document supports TPA Milestone M-13-80. Subsequent to the publication of the compendium, the data will be collected and made available to Ecology, EPA, and the public. This chapter addresses work that has not yet been performed to transfer the data. Data management will be a critical issue for the CRCIA throughout the life of the project. Some of the data management activities planned are: continued collection of existing contaminant data, transferring information to the public domain, and management of all data used in the project. This section is provided for the purpose of identifying how contaminant information will be transferred to the public domain.

\subsection{Ongoing Searches}

The effort to collect existing data applicable to the objectives of this project will continue after the publication of the data compendium. An attempt will be made to locate all data brought to the attention of the CRCIA project staff. Also, when relevant data are identified, an additional search will be made for other efforts by the people and organizations who produced the data.

\subsection{Methods for Transferring Data to the Public}

All data used in calculations by the CRCIA staff will be placed in the public domain. Information will be considered to be in the public domain when it is placed in a publicly available database, or when it is delivered to the DOE Reading Room in Richland, Washington.

The methods used to transfer information into the public domain will vary according to the format and current availability of the information. This transfer process will be used for some information gathered during the data compendium effort, and will continue to be used throughout the project to move data or other pertinent information into the public domain.

\subsubsection{Transfer Methods for Paper Documents Based on Current Availability}

Documents (or microfilm) containing data on contamination in the Columbia River that are not already in the public domain, fall into one of the following categories:

- they were approved for public release by the funding organization, but were not provided for public distribution

- they were written for internal company or client use, but were never approved for public release.

The method for making these documents available for the CRCIA will vary according to the originating organization. 


\subsubsection{Documents Already Approved for Release}

The data compendium search has located some documents thought to contain information about contamination of the Columbia River that have been approved for public release, but that were never made available to the general public. These documents will be made available to the public by transmitting a copy to the DOE Reading Room in Richland. The documents identified in Section 4.2.7 have already been transmitted to the DOE Reading Room.

\subsubsection{Documents Approved Only for Company or Client Use}

The data compendium search has located some documents that have been approved for internal use by the sponsoring organization, but that were never approved for public release. The CRCIA project staff will work with the author, the author's employer, and DOE to attempt to obtain permission to release the document to the public.

PNL Letter Reports are examples of this category of information. Letter Reports are informal reports that generally are released only to the client sponsoring the work. They have not been subjected to all of the steps in the PNL clearance process for documents that will be publicly available.

\subsubsection{Unpublished Documents and Records}

The data compendium search has located some contaminant data that were never published. CRCIA project staff will work with the information originator or DOE to attempt to obtain permission to publish the information. The typical and expected publication approach is to publish the data without any analysis under a cover letter acknowledging the individual or organization that collected the data.

\subsubsection{Transfer Methods for Information in a Non-Paper Form}

Several databases containing contaminant information in electronic form were identified in the data compendium search. The major databases identified in the data compendium search are described in Appendix C. Because the data are in electronic form, they are useful only to individuals who have a computer and who want to perform analyses on the data. Several options are present for making databases available. These options include:

- placing a disk copy of the database, or the applicable part of the database, in the public domain

- granting access across a computer network to the database

- $\quad$ providing a paper copy of the information.

CRCIA staff will work with DOE to establish a method for granting database access for those interested organizations or individuals who wish to perform their own analyses. The method being considered at this time is to place the information in the Hanford Environmental Information System (HEIS) and grant access to the information through the process set up by TPA agencies (Brulotte and 
Christensen 1993). This process allows an electronic guest access for individuals who are not DOE, EPA, or Ecology employees.

\subsection{Description of CRCIA Databases}

Two databases will be needed to track the data used in the CRCIA. The first database will contain references and bibliographic information for documents. The second database is a numerical one to track all numerical data used in CRCIA calculations.

\subsubsection{Reference Database}

A Columbia River Reference Database (CRRD) is being developed to contain complete references for any information considered applicable to the CRCIA. This database is being developed in two phases. An initial phase was implemented for use in organizing references for this data compendium. A limited amount of bibliographic information and document availability status is incorporated in the first phase of this database.

In future phases, a reference entry in the CRRD will contain bibliographic information and a short annotation including such items as: the organization performing the work, sample locations, report period, environmental media included, contaminants discussed, and data accessibility. Information for entries in the final CRRD will be gathered through use of a checklist that will be completed for all material reviewed for the CRCIA. If the information is not considered useful to the project, the checklist will be filed in project records. If the information is found to be useful, an entry will be made in the reference database. This database could then be used to find a list of documents that discussed, for instance, chromium contamination in the Columbia River.

\subsubsection{Numerical Database}

A numerical database will be used to serve as a repository for all data used in the CRCIA. This database will include both primary data and supporting data. Primary data are any data used for calculations in project activities. Supporting data may be corroborating data for primary data. All data in the numerical database will have one or more links to references in the reference database.

Options are currently being studied for the appropriate platform for the numerical database. Public access to the CRCIA project data will be an issue. The method primarily being considered at this time is to place the information in the Hanford Environmental Information System (HEIS) and grant access to the information through the process set up by TPA agencies (Brulotte and Christensen 1993). This process allows an electronic guest access for individuals who are not DOE, EPA, or Ecology employees. 


\subsection{References}

Brulotte, P. J. and K. C. Christensen. 1993. Tri-Party Agreement Databases, Access Mechanism and Procedures. DOE/RL-93-069. U.S. Department of Energy, Richland, Washington.

Cushing, C.E., D.G. Watson, A.J. Scott, and J.M. Gurtinsen. 1981. "Decrease of Radionuclides in Columbia River Biota Following Closure of Hanford Reactors." Heaith Physics 41(1):59-67.

Dirkes, R. L., G. W. Patton, and B. L. Tiller. 1993. Columbia River Monitoring: Summary of Chemical Monitoring Along Cross-Sections at Vernita Bridge and Richland. PNL-8654. Pacific Northwest Laboratory, Richland, Washington.

Dirkes, R. L. 1994. Summary of Radiological Monitoring of Columbia River Water Along the Hanford Reach, 1980 Through 1989. PNL-9223. Pacific Northwest Laboratory. Richland, Washington.

Ecology, EPA and DOE. 1989. Hanford Federal Facility Agreement and Consent Order. Washington State Department of Ecology, U.S. Environmental Protection Agency, and U.S. Department of Energy, Olympia, Washington.

Ecology, EPA and DOE. 1994. Hanford Federal Facility Agreement and Consent Order, Fourth Amendment, January 1994. Washington State Department of Ecology, U.S. Environmental Protection Agency, and U.S. Department of Energy, Olympia, Washington.

Robeck, G. G., C. Henderson, and R. C. Palange. 1954. Water Quality Studies on the Columbia River. U.S. Public Health Service, U.S. Department of Health, Education, and Welfare, Robert A. Taft Sanitary Engineering Center, Cincinnati, Ohio.

U.S. Department of Energy. 1993. Columbia River Impact Evaluation Plan. DOE/RL-92-28 Rev.0. United States Department of Energy - Richland Operations Office. Richland, Washington.

Walters, W. H., R. L. Dirkes, and B. A. Napier. 1992. Literature and Data Review for the Surface-Water Pathway: Columbia River and Adjacent Coastal Areas. PNWD-2034 HEDR. Battelle, Pacific Northwest Laboratories. Richland, Washington.

Washington State Department of Health. 1993. Environmental Radiation Program 1991 Annual Report 30th Edition. Washington State Department of Health, Division of Radiation Protection, Environmental Radiation Section. Olympia, Washington.

Woodruff R. K. and R. W. Hanf (eds). 1993. Hanford Site Environmental Report 1993. PNL8682. Pacific Northwest Laboratory. Richland, Washington. 


\section{Appendix A}

\section{Published Information Not Currently Available to the Public}

Appendix $A$ is included in electronic form on the accompanying diskette in file APPENDIX.A. It contains references to approximately 2050 documents that were located during the data search, but which are not currently available at the DOE Reading Room in Richland.

\section{A.1}




\section{Appendix B}

\section{Formerly Classified Titles}

Appendix B is included in electronic form on the accompanying diskette. It is contained in two separate files: APPENDIX.B1 and APPENDIX.B2. The file APPENDIX.B1 contains references to 435 unclassified titles of formerly classified documents obtained from the tracking system at the Hanford Technical Library. The file APPENDIX.B2 contains 230 more unclassified titles of formerly classified documents. As of April, 1994, the reference information in file APPENDIX.E2 has not been entered into the tracking system at the Hanford Technical Library.

The information contained in this appendix is different from that contained in other appendixes in two ways:

- This appendix contains references for documents whose titles have been unclassified. Many of the documents are still classified.

- These document reference lists are provided as obtained from the Hanford Technical Library. PNL has not attempted to eliminate documents that may not be applicable to the CRCLA. 


\section{Appendix C}

\section{Description of Databases}

\section{Access to Hanford Originated Databases}

Several Hanford-related databases have already been identified as part of the TPA process (Brulotte and Christensen 1993). Access to these databases has been provided to Ecology and EPA. The following list identifies the Hanford TPA-related databases:

- $\quad$ Environmental Release System (ERS)

- Hanford Environmental Information System (HEIS)

- Hanford Geographical Information System (HGIS)

- Hanford Meteorological System (HMS)

- Liquid Effluent Monitoring Information System (LEMIS)

- $\quad$ Project and Data Management System (PDMS) in HEIS

- $\quad$ Solid Waste Information and Tracking System (SWTTS)

- Surveillance Analysis Computer System (SACS)

- $\quad$ Tank Characterization Database (TCD)

- Waste Information Data System (WIDS).

As documented in Section 5.3 of Brulotte and Christensen, some of the databases data will be accessed using HEIS, and a few databases will not have direct computer access. Brulotte and Christensen also provide an abstract of the data contained in each database. Based on those abstracts, and also on discussions with several database stewards, the following databases may contain data useful to the CRCIA: ERS, HEIS, HGIS, LEMIS, PDMS, and WIDS.

CRCIA staff will work with DOE to establish a method for granting database access for those interested organizations or individuals who wish to perform their own analyses. The method being considered at this time is grant access to the information through the process set up by TPA agencies (Brulotte and Christensen 1993). This process allows an electronic guest access for individuals who are not DOE, EPA, or Ecology employees.

\section{Northwest Environmental Database}

The Northwest Environmental Database (NED) contains information on rivers in Idaho, Montana, Oregon, and Washington. Data categories include: anadromous fish, resident fish, wildlife, natural features, cultural resources, recreation, institutional constraints, and water quality. Each of the four states maintains a Rivers Information System accessible to members of the public with a personal computer: Contacts include:

- Martin Hudson, Washington Rivers Information System, Washington Department of Wildlife, . Habitat Management Division, (206) 664-0383.

- Tom Pansky, Northwest Environmental Data Base Regional Coordinator, (503) 230-3969 
- Steve Gordon, Northwest Environmental Data Base Regional Data Manager, (503) 230-5063

- Peter Paquet, Northwest Power Planning Council, (503) 222-5161

\section{Surface Environmental Surveillance Project Database}

Activities on the SESP project includes sampling of river water, sediments, river banks, springs, fish, clams, crayfish, and riparian vegetation. Shoreline radiation dosimeters continuously collect monitoring data. Only radionuclides are monitored. The data are reported annually with spreadsheets available electronically. These data are being transferred into HEIS, but the transfer is not yet complete. The contact person for this database is Roger Dirkes, Pacific Northwest Laboratory, P.O. Box 999, Richland, WA, 99352.

\section{Wildlife Resources Project}

The 100 Area monitoring is designed to study effluents from the nuclear facilities, particularly the seeps and discharges from buildings, drain fields, and trenches. Springs and near-river soils, vegetation, and the ground water are monitored. Some small animal collection is done and near-river studies of soil and vegetation have been done near the 100 Area facilities. Data from these activities are reported annually and the associated databases are available electronically. These data are also being transferred into HEIS, but the transfer is not yet complete. The contact person for this database is Ted Poston, Pacific Northwest Laboratory, P.O. Box 999, Richland, WA, 99352.

\section{Hanford Dose Reconstruction Project (PNL)}

Four databases of historical information were generated by the Hanford Environmental Dose Reconstruction Project (HEDR). Brief database descriptions are:

- The Hanford Information Resource Tracking System (HIRTS) contains bibliographical information on all documents examined for the HEDR project. This database is available in the DOE Reading Room in Richland.

- The Environmental Monitoring Document Database (EMDD) contains an annotated bibliography of all the documents that contained key information for the air and river dose estimates prepared by the HEDR project. This database is available in the DOE Reading Room in Richland in both electronic and paper forms.

- A database was also developed by the HEDR project to manage all of the data required to construct estimates of the release of radionuclides to the Columbia River for dose reconstruction purposes (Heeb and Bates 1994). This database is available in the DOE Reading Room in Richland.

- A compilation of approximately 33,000 measurements of radioactivity in water, fish, and wildlife was developed for the HEDR project (Thiede and Duncan 1994). This database is also available in the DOE Reading Room in Richland. 


\section{References}

Brulotte, P. J. and K. C. Christensen. 1993. Tri-Party Agreement Datahases, Access Mechanism and Procedures. DOE/RL-93069. U.S. Department of Energy, Richland, Washington.

Heeb, C. M. and D. J. Bates. 1994. Radionuclide Releases to the Columhia River from Hanford Operations, 1944-1971. PNWD-2223 HEDR. Battelle, Pacific Northwest Laboratories. Richland, Washington.

Thiede, M. E. and J. P. Duncan. 1994. Database of Radionuclide Measurements in Columbia River Water, Fish, Water Fowl, Game Birds, and Shellfish Downstream from Hanford Single-Pass Production Reactors, 1960-1970. PNWD-2242 HEDR, Battelle, Pacific Northwest Laboratories. Richland, Washington. 


\section{Appendix D}

\section{Documents Already in the Public Domain}

Appendix $D$ is included in electronic form on the accompanying diskette in the file APPENDIX.D. It contains references to 1750 documents that can be found at the DOE Reading Room in Richland.

D.1 


\section{Distribution}

No. of

Copies

Offsite

12 DOE Office of Scientific and Technical Information

B. Aripa

Environmental Trust

Colville Confederated Tribes

P.O. Box 150

Nespelem, WA 99155

L. Block

U. S. Fish and Wildlife Service

Moses Lake Field Office

P.O. Box 1157

Moses Lake, WA 98837

D. Bonga

Kalispel Tribe

P.O. Box 39

Usk, WA 99180

D. Bradshaw

Audobon Society of Portland

5151 Northwest Cornell Road

Portland, OR 97210

N. Buske

Search Technical Services

Star Route Box 17

Davenport, WA 99112

D. Cellarius

Sierra Club Northwest Office.

1516 Melrose Avenue

Seattle, WA 98122
No. of

Copies
C. Cline

Washington State Dept. of Ecology

Mail Stop PV-11

P.O. Box 47651

Olympia, WA 98504-8711

F.R. Cook

2552 Harris

Richland, WA 99352

J. P. Corley

2213 Torbett

Richland, WA 99352

DNR Hanford Projects

Attn: J. R. Wilkinson

Confederated Tribes of the Umatilla

Indian Nation

P.O. Box 638

Pendleton, OR 97801

G. De Bruler

Columbia River United

P.O. Box 667

Bingen, WA 98605

C. Denniston

Greenpeace

11815 - 20th SW

Seattle, WA 98146

B. Drost

USGS Water Resources Division

Washington District

1201 Pacific Avenue Suite 600

Tacoma, WA 98402

Distr. 1 


\section{Distribution}

No. of

Copies
No. of

Copies
D. Dunning

Oregon Dept. of Energy

625 Marion Street NE

Salem, OR 97310

J. Erickson

Division of Radiation Protection

Washington State Dept. of Health

P.O. Box 47827

Olympia, WA 98504-7827

D. Ernst

Planning Department

Spokane Tribe

P.O. Box 100

Spokane, WA 99040

M. Fox, President

Hanford Family

P.O. Box 1462

Richland, WA 99352

D. Frank, Tribal Chairman

Confederated Tribes of the Warm Springs Reservation

Warm Springs, OR 97761

N. J. Germond

League of Women Voters

224 Iron Mountain Boulevard

Lake Oswego, OR 97034

R. Jim

Confederated Tribes and Bands of the

Yakama Indian Nations

P.O. Box 151

Toppenish, WA 98948
C. Mebane

National Oceanic and Atmospheric

Administration

c/o EPA Seattle Office

1200 6th Avenue, HW-113

Seattle, WA 98101

J. Monteith

Oregon Natural Resources Council

1161 Lincoln Street

Eugene, OR 97401

E. Patawa, Chairman

Confederated Tribes of the Umatilla

Indian Reservation

P.O. Box 638

Pendleton, OR 978014

R. Patt

Water Resources Department

555 13th Street, NE

Salem, OR 97301

S. N. Penney, Chairman

Nez Perce Tribal Executive Council

P.O. Box 305

Lapwai, ID 83540

G. Pollet, Ex. Director

Heart of America Northwest

1305 4th Avenue, 208

Seattle, WA 98101

D. Powaukee

Nez Perce Tribe

P.O. Box 365

Lapwai, ID 83540

Distr. 2 


\section{Distribution}

No. of

Copies
No. of

Copies
M. Queahpama

Vital Statistics

Confederated Tribes of the Warm

Spring Reservation

P.O. Box C

Warm Springs, OR 97761

D. Reicher

Natural Resources Defence Council 1350 New York Avenue NW

Suite 300

Washington, DC 20005

L. Seyler

Cour d'Alene Tribe

Plummer, ID 83851

A. P. Slickpoo, Sr.

809 Nez Perce Lane

P.O. Box 311

Kamiah, ID 83536

\section{Stembridge}

HEAL

1408 West Broadway Avenue

Spokane, WA 99201-1902

D. Stewart-Smith

Oregon Department of Energy

625 Marion Street NE

Salem, OR 97310

W. L. Templeton

2331 Enterprise Drive

Richland, WA 99352
J. P. Thomas

HHIN Resource Center

1719 Smith Tower

506 Second Avenue

Seattle, WA 98104

D. Wells

Division of Radiation Protection

Washington State Dept. of Health

P.O. Box 47827

Olympia, WA 98504

W. Yallup, Chairman

Yakama Tribal Council

Yakama Indian Nation

P.O. Box 151

Toppenish, WA 98948

Onsite

14 DOE Richland Operations Office

B. L. Foley (7)

K. M. Thompson

P. K. Willison

DOE Public Reading Room (5)

A5-19

A5-19

A $4-52$

$\mathrm{H} 2-53$

5 Washington State Department of

Ecology

J. W.Yokel

B5-18

D. P. Holland (4)

B5-18

4 Westinghouse Hanford Company

Administrative Record (3)

A. S. Carlson

H6-08

B3-35

Distr. 3 


\section{Distribution}

No. of

Copies

6 U. S. Environmental Protection Agency

L. E. Gadbois (5)

B5-01

D. R. Sherwood

B5-01

33 Pacific Northwest Laboratory

G. L. Black (5)

B1-34

S. L. Cannon

R. L. Dirkes

P. W. Eslinger (5)

S. L. Friant

R. H. Gray
No. of

Copies
M. S. Hanson K1-51

G. L. Harvey K2-02

P. C. Hays

L. R. Huesties

A. D. Maughan

T. B. Miley

B. A. Napier

D. B. Shipler

S. F. Snyder

W. H. Walters

B. K. Wise

Records Center (2)

Publishing Coordination

Technical Library (5)
K6-86

K6-61

K6-52

K7-34

K3-54

B1-34

K3-54

K $6-60$

K1-71

K3-70

K1-06

P8-55

Distr. 4 